\title{
Financial decisions of the financially literate *
}

\author{
Nicolas AUBERT ${ }^{\dagger}$ \\ Niaz KAMMOUN $\ddagger \S$ \\ Yacine BEKRAR $\mathbb{I}$
}

July 2018

\begin{abstract}
This paper investigates the portfolio performance of the company-based savings of a cross section of approximately 30,000 employees of a listed French bank.

We have detailed information about each job position in the bank, which enables us to study the employees' financial literacy, specific knowledge of the plans offered, and private information. These better-informed bank employees supposedly adopt behavior that is the closest to that of an informed rational investor. We explore the employees' portfolio performance in the savings plans and find that financial expertise and knowledge of the plans are related to participation in the plans offered by the company. Financial expertise is related to better employee stock purchase plan (ESPP) individual portfolio performance but not to the company-based savings plan (CSP) and the overall performance of the company's plans. For both offered plans, participation is more likely among the job categories (including finance experts), female employees, more educated employees and less financially constrained employees. We find evidence of the mental accounting of company stock highlighted by Benartzi and Thaler (2001).
\end{abstract}

KEYWORDS: Household finance, bank employees, employee-based savings

JEL CLASSIFICATION: G11, G23, G32, G34, H31

\footnotetext{
*We wish to thank participants of the world finance association conference 2016, the French Finance conference 2017, the Aix-Marseille University doctoral school day 2016, Riccardo Calcagno, Patrick Roger and two anonymous referees for their comments

${ }^{\dagger}$ Aix Marseille University, CERGAM, Puyricard, France (niaubert@gmail.com)

${ }^{\ddagger}$ Paris-Sud University, RITM, Sceaux, France (niazkammoun@gmail.com)

$\S$ Aix Marseille University, CERGAM, Puyricard, France

IToulon University (bekraryacine@hotmail.fr)
} 


\section{Introduction}

Although most twentieth-century financial crises had little to do with retail investors, a major cause of the subprime crisis was investors' lack of financial knowledge. Understanding household-investment behavior is challenging, as households' savings decisions are associated with major welfare costs, as shown by Bhamra and Uppal (2016). Individual investors often rely on their bankers' advice. But do the most financially literate people apply the advice they give to their customers to their own saving decisions? Lusardi and Mitchell (2014) define financial literacy as "people's ability to process economic information and make informed decisions about financial planning, wealth accumulation, debt, and pensions" (p. 6). Not only do bank employees have better access to financial advice and information but some hold positions that require expertise in financial decision making. Therefore, bank employees can be defined as financially literate people who are less likely to "misbehave" in the sense of Richard Thaler (2015), i.e., to adopt behavior that departs from the core premise of economic theory. According to Thaler (2015), "The core premise of economic theory is that people choose by optimizing." This premise is combined with the equilibrium principle. Most of the advice given by financial advisors is taken from modern portfolio theory and is inspired by the findings of economic theory applied to financial markets. The premises of economic theory were challenged by the work of Richard Thaler. This paper investigates the individual portfolio performance of a sample of bank employees within their company-based savings plans. The aim is to document the link between objective measures of financial literacy or expertise and company-based savings portfolio efficiency. We look at the company-based savings composition and risk/return characteristics for a cohort of approximately 30,000 French bank employees. We observe savings invested in the plans offered by the company they work for, including their employer's stock. We use this comprehensive dataset, comprising detailed information on each employee's job characteristics and details of the investment options selected by them. This original dataset enables us to measure financial literacy and job characteristics with secondary data. Previous literature, with the exceptions of Boolell-Gunesh et al. $(2009,2012)$ and Feng and S. Seasholes (2005), often measure self-reported financial literacy by relying on survey data. In addition to financial expertise, our dataset also enables the measurement of several employee characteristics, including specific knowledge of the plans and private information. Calcagno and Monticone (2015) and Hackethal et al. (2012) relied on samples of bank customers to investigate the consequences of financial advice. Calcagno and Monticone (2015) show that bank advisors are not sufficient to alleviate the problem of financial literacy, whereas Hackethal et al. (2012) find that advised customers have a lower risk-return trade-off 
ratio (measured by the Sharpe ratio). These results may be a consequence of poor financial advice. In addition to measuring the financial literacy of bank employees, we also directly observe the performance of financial advisors, i.e., the front-line staff. This paper is innovative because it investigates the investment behavior of bank employees, who are considered to be the closest to rational and informed economic agents. Indeed, bank employees are well informed because of the sector to which their companies belong. They benefit from reduced fixed-participation costs by having easier access to financial information. Furthermore, we focus on data concerning company-based savings plans offered by the bank to all its employees. All the employees have easy access to the same information through a variety of ways. The employees have online, secured access to the information about their company-based savings (e.g., key investor information documents, historical prizes). There are also opportunities for arbitrage within the plan. Within the workplace, bank employees also benefit from the advice of their more financially literate colleagues, for instance, those who are specifically in charge of advising customers about how to invest their savings. We use a dataset that makes it possible to identify employees who hold a position that requires better-than-average financial literacy. Another original element of this paper is its focus on two types of company-based savings plans: a company savings plan (CSP) with features similar to those of the 401(k) in the US, and an employee stock purchase plan (ESPP). We measure portfolio efficiency for all the plans and for each plan separately. This feature enables testing of whether mental accounting affects the employees. This cognitive phenomenon identified by Thaler (1985) consists of psychologically separating the plans and considering them as non-fungible. In other terms, the employees would separately optimize the two plans. The remainder of this paper is structured as follows. Section 2 presents a literature review and hypotheses development. Section 3 describes the empirical strategy, and section 4 presents the results. In the latter section, we provide descriptive statistics of the employees' portfolio efficiency according to their job characteristics. We also analyze employees' portfolio efficiency according to the financial literacy and job-category variables affecting portfolio efficiency. Among the employees in our dataset, some are trained to understand the financial markets, some know the administrative functioning of the plans, and some are likely to hold private information about the company's future returns. We find that financial expertise and knowledge of the plans are always related to participation in the plans offered by the company. Financial expertise is related to better ESPP individual portfolio performance but not to overall and CSP performance. For both plans offered, participation is more likely among most job categories (including finance experts), female employees, more educated employees and less financially constrained employees. This first set of results is con- 
sistent with Babenko and Sen (2014). We find evidence of the mental accounting of company stock highlighted by Benartzi and Thaler (2001) since the characteristics related to portfolio performance are not the same for the ESPP, which is invested exclusively in company stock, and the diversified CSP. Section 5 discusses the results, and section 6 concludes.

\section{Literature review and hypotheses development}

The problem of employees' overinvestment in employer's stocks has been extensively investigated after Enron's bankruptcy at the beginning of the 2000s (Benartzi et al., 2007). The investigation of employees' investment in their company savings plans, such as the American 401(k), has triggered research on behavioral and household finance in the 2000s. The overinvestment in employers' stock by US workers caught the attention of Richard Thaler and his colleagues and has become a major field of experimentation for behavioral finance (see Benartzi et al. (2007) for a review). Richard Thaler published several papers on this specific issue. Benartzi and Thaler (2001) report that offering company stock to employees significantly affects their portfolio choices. They highlight the "mental accounting of company stock", which involves putting the company stock into its own separate asset category, different from that of other equities. As the company stock is not considered to be as risky as other stocks, this cognitive phenomenon results in riskier and under-diversified portfolios. However, from a rational investor standpoint, the cost of investing in an employer's stock, as computed by Meulbroek (2005) and Ramaswamy (2003), is prohibitive. Behavioral finance recognizes that employees' investment in their company stock is a consequence of cognitive biases, such as excessive extrapolation of past returns and endorsement (Benartzi, 2001), endowment (Thaler, 1980), the framing effect (Benartzi and Thaler, 1999, 2002), loyalty and familiarity (Cohen, 2009, Huberman, 2001), risk myopia (Mitchell and Utkus, 2003), the disposition effect (Choi et al., 2004), and default heuristics (Benartzi, 2001; Madrian and Shea, 2001). We hypothesize that more financially literate investors are not affected by such cognitive biases. Employer-stock investment has been extensively studied in the context of the US 401(k) pension plan (Benartzi et al., 2007) and rarely outside the US within other investment contexts. One important question addressed by Richard Thaler is "Could we use behavioral economics to make the world a better place?" (Thaler, 2015; p. 307). Thaler and Benartzi (2004) note that individual investors have to face several behavioral challenges when they decide to save for their retirement: self-control, inertia, framing and loss aversion. As Benartzi says himself in a TED talk, Thaler and he "came up with an embarrassing simple solution 
called Save More, not today, Tomorrow"'1 1 Save More Tomorrow (the SMarT program) is a savings plan designed to help employees to save more in their 401(k) pension plan (Thaler and Benartzi, 2004). "The basic idea is to give workers the option of committing themselves now to increasing their savings rate later, each time they get a raise" (Thaler and Benartzi, 2004; p. S166). Thaler and his colleagues focused mostly on the 401(k), putting aside other companybased savings plans. In particular, the ESPP is a popular way to invest in employer stock. To the best of our knowledge, only Degeorge et al. (2004), Engelhardt and Madrian (2004), Rapp and Aubert (2011) and Babenko and Sen (2014) investigate employee investment in ESPPs. The ESPP offers a different context within which investment in company stock can be studied. In the US, Engelhardt and Madrian (2004) document a substantial non-participation rate, even though the ESPP they studied offers an opportunity for employees to increase their gross compensation. They find that liquidity constraints, imperfect knowledge of the plan, asset choice and transaction costs affect ESPP investment. Rapp and Aubert (2011) confirm these results in France. Babenko and Sen (2014) find that participation is more likely among employees who are familiar with stocks, more educated, less financially constrained, and those who make fewer errors in valuing financial securities. US employees can sell their discounted stocks at the market prize a day after buying them. Consequently, ESPP investment is a very attractive investment consisting in a riskless profitable operation. However, the authors document that only $30 \%$ of eligible employees take advantage of this opportunity. In general, employee stock ownership is a major way for individual investors to access the stock market. Approximately 23 million US workers (National Center for Employee Ownership, 2014) and eight million EU workers (European Federation for Employee Share Ownership, 2015) own stock in the company they work for.

With the pioneering works of Thaler, the investigation of household-investment behavior has become a new field in finance (Guiso and Sodini, 2013). Among other factors, the funding of pension and social security systems is closely connected to direct or indirect individual investor choices, and the investor's rationality assumption is challenged by individual investor strategies. Understanding the determinants of economic agents' portfolio performance is therefore a major concern since it has implications for the calibration of the optimal portfoliochoice model, the micro-foundations of the asset-pricing theory with heterogeneous agents, the asset-pricing debate on the time-varying preferences of investors, and the assessment of the welfare cost of investment mistakes, such as under-diversification and non-participation in financial and insurance markets (Guiso and Sodini, 2013). Guiso and Sodini (2013) consider

\footnotetext{
${ }^{1}$ https ://www.ted.com/talks/shlomo_benartzi_saving_more_tomorrow?language=en
} 
the revealed-preferences approach and elicitation-of-risk preferences as two empirical streams of literature investigating the determinants of risk preference. The risk-preferences approach relies on the observation of secondary data reflecting actual investors' decisions and infers their risk preferences. We adopt the risk-preferences approach, assuming that the risk preferences of the bank employees we investigate are revealed by the compositions of their portfolios. Transaction costs are another challenge individual investors face. Transaction costs are closely connected to the financial knowledge of individual investors. Indeed, a lack of financial expertise results in higher search costs, i.e., the cost an investor has to bear to understand the functioning of financial products and to make relevant decisions accordingly. According to Lusardi and Mitchell's review (2014), financial knowledge is a form of investment in human capital. Academic research relies exclusively on survey data-objective (actual knowledge) and subjective (self-assessed) questions - to evaluate financial literacy. Surveys identify three major concepts to assess financial literacy: numeracy and capacity to do calculations related to interest rates, such as compound interest; understanding of inflation; and understanding of risk diversification (Lusardi and Mitchell, 2014; p. 10). The survey questions on risk diversification obtain the weakest proportion of good answers, which reveals that risk diversification is clearly an issue.

Our dataset enables the measurement of most of the variables related to retail investors' risk exposure that are included in previous research. Putting aside financial literacy, we include proxies of the determinants of portfolio choices: human capital (age, salary, education level and job categories: commercial, logistics, administrative and other staff), specific human capital (years employed), liquidity constraints (wealth, salary, bonus, permanent contract), specific knowledge of the plan (HRM staff) and private information (hierarchical rank). Common variables causing risk exposure and affecting portfolio performance identified by the literature are wealth and background risk: sociodemographic characteristics are used as a proxy. Wealth has always been considered to be a cause of risk exposure (Von Neumann and Morgenstern, 2007; Merton, 1969). In this relationship, relative risk aversion is a key determinant, although it is not directly observable. Several empirical papers document decreasing relative risk aversion (DRRA), showing that when investors are wealthier, they invest a larger fraction of their wealth in risky assets. Blume and Friend 1975) pioneered this group of research using cross-sectional data on individual portfolios. Their findings were recently confirmed by Brunnermeier and Nagel (2008) and Chiappori and Paiella (2011). Calvet et al. (2009) and Calvet and Sodini (2014) establish the same relationship between wealth and risk exposure using panel data techniques, making it possible to control for endogeneity. Background risk cannot 
be avoided because it cannot be traded or insured. Merton's model (1969), which assumes that investors hold tradable assets and human capital, does not have this characteristic. Housing wealth (Flavin and Yamashita, 2002) and private business property (Heaton and Lucas, 2000) are also commonly identified as sources of background risk. Human capital is difficult to measure. One of the main drawbacks of revealed-preferences measures of risk aversion is that they do not consider human capital, a major component of individual investors' wealth. Therefore, revealed-preferences measures are likely to underestimate risk aversion. Because most laborincome risk is non-hedgeable, it increases risk aversion, leading households to invest more cautiously than predicted by the models. However, this assertion is debated. Some authors assume that labor income can be considered to be a safe asset (Cocco, 2005), positively correlated with capital income in the long run (Benzoni et al., 2007), or negatively correlated with capital income (Storesletten et al., 2007). Human capital decreases with age and increases with education. The present value of human capital is a function of the current salary and the time over which the salary will be received. Thus, younger workers have more human capital than do older workers. Age is also correlated with risk-aversion parameters (Dohmen et al. 2011). Viceira's model (2001) predicts that employees approaching retirement age are afraid to lose their savings and are not encouraged to invest in risky assets. Education increases the value of human capital. Haliassos and Bertaut (1995) also argue that education allows individuals to overcome the "barrier to stockholding". Consequently, more educated households invest in riskier assets. Campbell (2006) concludes that education directly predicts equity ownership. Experiments emphasize that women are more risk-averse than men (Croson and Gneezy, 2009). Lusardi and Mitchell (2014) also report significant links between financial literacy and age, gender, education and ability, place of residence (rural/city), income, and employment type. Specific human capital is highly related to the employment characteristics that we are able to account for in this paper.

Several papers using French data focus on the general trading activity and portfolio choices of retail investors. Using a large sample covering eight years, Roger (2014) builds a market sentiment index to predict short-term returns on long-short portfolios based on size or on the book-to-market ratio. Similarly D' Hondt and Roger (2017) investigate investor sentiment on two subsamples decomposed according to their appetite for information and professional advice. They highlight that investors who disregard free information and professional advice earn future returns on a long-short portfolio based on size. Broihanne et al. (2014) use survey data assessing the overconfidence of a sample of finance professionals to predict future stock prices. They use an overconfidence measure to highlight how risk perception and overconfi- 
dence can influence the risk-taking behavior of professionals. In the same vein, Boolell-Gunesh et al. (2012) underline how some particular psychological traits of retail investors are related to trading activity. They show that retail investors are prone to the disposition effect. Some individual characteristics, such as financial sophistication, are strongly related to trading behavior and more efficient financial decisions (Boolell-Gunesh et al., 2009).

The previous literature discussed existing empirical results and theoretical predictions concerning the relationship between individuals' financial literacy and their portfolio choices. This literature forms the basis of our main hypotheses. Given the previous literature on financial expertise and since we investigate employees' participation in the plans and their individual portfolio efficiencies, we expect the following:

Hypothesis 1: More financially literate employees have higher participation rates in companybased savings plans.

Hypothesis 2: More financially literate employees have better portfolio performance in company savings plans.

\section{Empirical strategy}

\subsection{Data and variables identification}

French company-based savings have some specific features. "The company savings plan (in French Plan d'Epargne Entreprise) enables employees to build up savings in the form of a portfolio of securities with the help of their company. Blocked for a minimum period of 5 years, the sums held come from voluntary payments made by the employees topped up by the company. The PEE can also be fed by profit-sharing" [2 Company-based savings plans in France were put in place in the 1960s and have been a way for individual investors to access the financial markets. In contrast to the US pension system, which was developed in the 1970s and allows individual investors to invest their savings in the financial markets, the French pension system remains mainly public. Within the CSP, employees are offered several investment options. Some of the funds are invested in the employer's stock. In the investigated data, one option offers the opportunity to invest in company stocks. In terms of investment choices, the CSP functions in a very similar way to the $401(\mathrm{k})$ pension plans of the US Internal Revenue Code, where employees have several investment options to choose from. French companies can also offer their employees the chance to invest in ESPPs. In both CSPs and ESPPs, investments are blocked for five years and benefit from the same tax benefits.

\footnotetext{
${ }^{2}$ Definition from the INSEE website (the French National Statistics Agency): https://www.insee.fr/en/metadonnees/definition/c1948
} 
Some reasons for early withdrawals, such as marriage, a child's birth, disability, death, etc., are accepted by French law. This constraint is offset by some benefits, such as a discount on the stock price and matching contributions offered by the employer, free arbitrage between the funds within the plan, tax benefits, and payments of management fees by the company. In the company we study, all the employees benefit from the same advantages.

We analyze a cross section of 29,432 employees of a French (CAC 40) listed bank who are eligible to participate in the CSP and ESPP. We match three different set of variables: the individual portfolio characteristics (ESPP and CSP), the employees' demographic characteristics, and the employees' job characteristics. The individual portfolio characteristics are used to compute dependent variables. The two latter sets of variables described below are independent variables that include proxies of determinants of portfolio efficiency emphasized in the literature review: financial literacy (finance expert), human capital (age, salary, education level and job categories: commercial, logistics, administrative and other staff), specific human capital (years employed), liquidity constraints (wealth, salary, bonus, permanent contract), specific knowledge of the plan (HRM staff) and private information (hierarchical rank). The description of the variables is reported in Table 1 (this table, and all others referenced in the paper, can be found in the Appendix).

The first group of variables contains the company-based savings variables. This group is used to compute the dependent variables of the regression analyses: the individual employees' portfolio mean returns on CSP, ESPP, and both plans; the individual employee's portfolio standard deviation of returns on CSP, ESPP, and both plans; and the individual employee's portfolio performance for CSP, ESPP, and both plans. Hackethal et al. (2012) and Roger (2014) use the Sharpe ratio as a measure of the risk-return trade-off in a French context; we also use the Sharpe ratio. The data on employees' demographics and job characteristics were initially collected in 2005 by the human resource management (HRM) department of the bank. To compute the risks, returns, and portfolio performance for each employee, we required the historical returns of the funds offered by the company. We received access to this data in 2011. The reason for this time lag is that the historical returns of the funds offered within the company-based savings plans (in French fonds communs de placement entreprise) are not publicly available. We obtained access to these data through the asset management subsidiary of the bank. Detailed descriptions of the features of the CSP and ESPP and the investment options offered within the plans are displayed in Panels A and B of Table 2. Seven funds are offered to the employees: five are part of the CSP and two are part of the ESPP. The standard deviation of returns, mean returns and Sharpe ratio associated with 
each of the seven funds are reported in Table 2. Five investment options are available in the CSP: company stocks, monetary assets, and three diversified assets (eurozone stocks, eurozone bonds, and international stocks). The benchmarks are composite indexes, which are also detailed in Table 2, The ESPP allows employees to invest in employer stock in two different ways: a classic offer and a leverage formula (the multiple offer). The classic offer consists of direct investment in company stock. These two offers both provide a $20 \%$ discount on the stock price. Participants pay the subscription price of the classic offer in full. In both investment options, dividends are automatically reinvested in the plan. For the ESPP, employees must be in line with a calendar provided by the employer. Although the ESPP is advertised long before its availability, the period during which the employees can invest lasts two weeks. The multiple fund was also offered to the employees of France Telecom (now Orange) during its privatization, as studied by Degeorge et al. (2004) For France Telecom's ESPP, the authors' neoclassical model predicts overwhelming participation rates and amounts invested in the multiple offer called 'Multiplix'. Their empirical results do not support this prediction. They interpret this result as a consequence of a high fixed-analysis cost due to the complicated offerings of Multiplix, which deterred employees from selecting it. Panel A of Table 2 describes the characteristics of the different funds offered to employees, while Panel B of Table 2 provides information about the legal constraints applied to the company-based savings plans. We also report the risk return characteristics of the funds. The Sharpe ratios range between -0.45 and 1.68. For comparison, the Sharpe ratio of the French reference index (CAC-40 ) during the same period was 1.45. The least efficient fund is the money fund, with a Sharpe ratio of -0.45 . The diversified fund, which is invested mostly in eurozone country bonds, has the highest Sharpe ratio, at 1.68. The multiple fund previously investigated by Degeorge et al. (2004) has a Sharpe ratio of 0.62 .

The second group of variables are the employee-level demographic variables, including age and gender. We create a dummy variable that takes a value of 1 if the employee lives in a large city of more than 200,000 inhabitants and 0 otherwise. We also have information about education levels, ranging from 1 to 5 (1: secondary school degree; 2: high school diploma; 3: bachelor's degree; 4: master's degree; 5: master's degree and higher). We do not have access

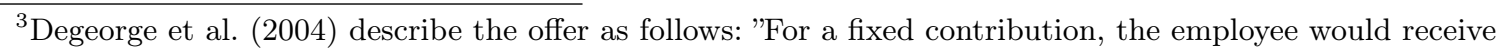
back a prespecified amount of money (like a bond) and also obtain the upside on ten shares. While not described in these terms, Multiplix delivered the economics of a bond-plus-call portfolio or alternatively a protected-put position. Legally, this payoff was delivered through a peculiar "guaranteed" loan that allowed the employee to buy nine additional shares for each share purchased through personal contributions. What makes this loan unusual is that the repayment is effected through the withholding of the dividends and tax credits (over the five-year life of the plan) and a variable repayment schedule at maturity that was a function of the ultimate France Telecom stock price. In effect, the loan repayment amount was equal to the positive difference between the value of ten shares less the payoff to the employee. The employee was never required to repay more than the value of his or her shares after five years" (p. 173).
} 
to information about employees' wealth outside of company savings; therefore, we follow Degeorge et al. (2004) by matching the town zip code and French national statistics agency (INSEE) localized tax revenues system. 4 The logic of Degeorge et al. (2004) is that "the choice of residence is a function of wealth and given the large disparities between towns and neighborhoods, it captures some of the unmeasured variation in household wealth" (p. 181). Age and education level are proxies of human capital, and wealth is a proxy of liquidity constraint.

The third group of variables is related to employees' job characteristics. We include annual gross salary and bonuses in euros. A dummy variable takes a value of 1 if the employee has a permanent contract and 0 otherwise. The salary, bonus and permanent contract variables also capture liquidity constraints. We also know the number of years the employees have worked for the bank. The number of years worked at the bank is a proxy for the employees' human capital. The hierarchical rank is taken from an internal system ranging from 1 to 12 , with 1 being the lowest and 12 the highest. Highest-ranked employees are assumed to have superior information about the company prospects. An important feature of this paper is that we have detailed data on employees' job descriptions. A typology of 465 jobs is used by the bank. We use five dummies to characterize these categories. The variables are coded 1 if the employee belongs to the category and 0 if he does not. "Commercial staff" is recorded if the employee interacts with the bank's customers. Such employees are often in a position to advise their clients on the kinds of financial products to invest in. "Commercial staff" consists of 96 job categories and 15,720 employees. "HRM staff" are people who work for the human resource management service. We assume that these employees have superior knowledge of the functioning rules of the company-based savings plans. "HRM staff" includes 29 job categories and 672 employees. "Administrative staff" are involved in many different tasks, including management, accounting, quality and management control, auditing, credit analysis, legal, secretarial, and purchasing. These employees hold positions that do not require advanced knowledge of portfolio management. "Administrative staff" encompasses 227 job categories and 8,443 employees. "Logistics staff" are dedicated to technical tasks such as information technology, information systems, building management, mailing, social work, nursing, and cleaning. "Logistics staff" consists of 73 job categories and 1,048 employees. "Other staff" employees do not belong to any of the preceding categories. Approximately $75 \%$ of these employees belong to after-sales services. "Other staff" includes 45 categories and 3,549 employees. Another feature of our data is that the job categories allow us to identify financially literate employees. One can assume that the

\footnotetext{
${ }^{4}$ The localized tax revenues system reports the average taxable income from all potential sources of revenue.
} 
average knowledge of finance is better in a bank than in another sector. However, within a bank, we also have people who are more financially literate than others, and we can identify these employees with a specific dummy variable called "finance expert" staff. The variable is coded 1 if the employee belongs to this category and 0 otherwise. To compute this variable, we again screened all the job categories to see if they require financial expertise. Traders and portfolio managers belong to this category. "Finance expert" includes 50 categories and 3,386 employees. These job categories can also be coded in the five preceding categories. For instance, a private banking advisor is coded 1 for both the "finance expert" and "commercial staff" variables. Boolell-Gunesh et al. $(2009,2012)$ also use direct measures of retail investors' sophistication in the French context. They hypothesize that individuals trading derivatives, bonds, and foreign assets and holding multiple accounts are more sophisticated. They investigate the relation between sophistication and the disposition effect, a behavior identified by Shefrin and Statman (1985) and defined as the tendency of investors to hold losers too long and sell winners too soon. They conclude that sophisticated investors are also affected by disposition bias, although sophistication attenuates this effect (Boolell-Gunesh et al., 2009). They also find that more sophisticated individual investors correct their disposition bias over time (Boolell-Gunesh et al., 2012).

\subsection{Estimation model}

The dependent variable in our regression analyses is the individual portfolio Sharpe ratio for the CSP, the ESPP, and for both plans. In further analyses, we also regress the components of the Sharpe ratios (the individual volatility and returns) on the independent variables. The job-characteristic variables are our variables of interest. We also control our regressions for a set of demographic variables. We regress the individual Sharpe ratios on our set of independent variables using a two-step sample selection model (Heckman, 1979) ${ }^{5}$ Our dataset comprises information about employees who did and did not invest in the plans. This feature allows us to account for sample selection. The presence of potential selection bias may have occurred due to a combination of other, non-observable characteristics. Wooldridge (2015) recommends the use of an identification variable that is correlated with the first step (the decision whether to invest or not) but is not correlated with the Sharpe ratio in the second step. The inclusion of an additional identification variable in the first step that is omitted in the second step prevents an unobserved selection process. As an identification variable, we select the mean of the Sharpe ratio computed for each of the 465 job categories. We

\footnotetext{
${ }^{5} \mathrm{~A}$ detailed presentation of the method is provided by Wooldridge (2015).
} 
assume that employees belonging to the same job category have similar risk preferences and a similar probability of investing. Such an assumption is consistent with Goetzmann and Kumar (2008), who use three occupation dummies that are broader than ours as proxies for investor sophistication (professional: investors who hold technical or managerial positions; non-professional: investors who are blue-collar workers, sales and service workers, clerical workers, house-makers or students; and retired). Our identification variable is not correlated with the dependent variable.

The estimated equation can be written by considering the selection function:

$$
\begin{aligned}
& \left(S R_{* i}\right)=\sum_{n}^{N} \delta_{n} \omega_{n i}+\mu_{n} \\
& \left(S R_{*}\right)=1, i f\left(S R_{* i}\right)>0 \\
& \left(S R_{*}\right)=0, i f\left(S R_{* i}\right) \leq 0
\end{aligned}
$$

where $S R_{* i}$ is a latent variable that measures the probability to invest in the offer or not, $\omega_{n}$ is a set of $\mathrm{N}$ variables that represent the characteristics of employee $\mathrm{i}$ that influence the probability of participation in the offer, $\delta_{n}$ are coefficients that captures the effects of these variables on the probability of being a participant, and $\mu_{n}$ is an error term following a standard normal distribution with zero mean. The second step takes the following form:

$$
Y_{i}=\sum_{k} \beta_{n} X_{k i}+\mu_{i}
$$

The substantial equation is based on the conditional expectation of the observed variable, the Sharpe ratio $\left(Y_{i}\right)$ :

$$
E\left\{Y_{i} \mid S R_{* i}>0\right\}=X_{j} \beta+\rho \sigma_{u} \lambda\left(S R_{i} \hat{a}\right)+\epsilon_{i}
$$

where $\lambda$ represents the inverse Mills ratio (IMR). This selectivity term is constructed in the first step of the model and is introduced as an independent variable in the second step, known as the substantial equation. Indeed, the significance of the coefficient associated with the IMR in the second equation confirms the existence of selectivity bias in the selection equation. The second step of the Heckman procedure consists of estimating an ordinary least squares linear equation using the Sharpe ratio as the dependent variable. Indeed, the selection equation of the model is biased by sample selection since the coefficient of the IMR is significant. 


\section{Empirical results}

\subsection{Descriptive statistics}

Panels A and B of Table 3 provide descriptive statistics about the employees' participation in the plans. Panel A focuses on categorical variables, and Panel B reports statistics on continuous variables. Panel A shows that the participation rate in all plans is higher for females (60.22\%), small-city residents (88.36\%), less-educated employees (68.03\% are high school graduates, and the education of $17.39 \%$ is below this level), employees with a permanent contract (98.47\%), employees with a lower hierarchical rank (45.06\% between 3 and 6 , and $11.13 \%$ between 1 and 3), and employees without financial expertise (86.99\%). Regarding the job categories, the participation of HRM staff is higher (92\%, or 621 of 672$)$ than that of administrative staff (90\%), commercial staff (88\%), logistics staff (86\%), and other staff (84\%). Panel B of Table 3 shows that participants are as old as non-participants (mean $\approx 46$ years; $\mathrm{SD} \approx 10.77$ years), are wealthier (mean: $35,750 €>34,710 €$; SD: 8,688€ > 8,170.77€), are better paid (mean: 29,817€ > 26,079€; SD: 12,823€>6,154€), have a higher bonus (mean: $1,550 €>641 €$; SD: $5,945 €>1,336 €$ ), and have worked in the company for the same number of years (mean $\approx 26$ years; $\mathrm{SD} \approx 12$ years). Panel $\mathrm{B}$ of Table 3 also shows that participants in all plans earn a $9.51 \%$ average return (SD: $6.53 \%$ ) with a $9.95 \%$ average return volatility (SD: $10.23 \%)$, resulting in an average Sharpe ratio of 0.88 . Some outliers affect the distribution of the Sharpe ratios for the ESPP and the CSP. The minimum negative and extremely low values of the ratios are concerning. These values are due to the very high concentration of some employees' savings in the money fund associated with very low volatility in the denominator and a negative difference between the fund return and the risk-free rate in the numerator. This feature of the data suggests that these employees invest massively in liquidity, which is the default option, i.e., the option selected automatically if the employees do not make a choice. The literature refers to this behavior as the default choice heuristic. As a consequence of inertia, another form of behavioral bias, the employees stick to this default choice and do not subsequently rebalance their portfolio. When we remove these outliers (678 for the ESPP and 860 for the CSP), the return and volatility are not affected, and only the Sharpe ratio statistics change (mean Sharpe ratio: 0.31 for the ESPP and 0.9 for the CSP; minimum: -0.48 for the ESPP and 0.06 for the CSP; SD: 0.24 for the ESPP and 0.32 for the CSP). We run the regressions without the outliers. We consolidate our results by considering regressions with outliers but using a robust estimator (see comments about how the results are affected in the additional tests and robustness checks section).

Table 4 displays the participation rates (Panel A) and the amount invested (Panel B) 
according to the funds and plans offered. For the ESPP participants, the participation rate is higher in the multiple offer $(83.77 \%)$ than in the classic one $(49.54 \%)$, with a higher average amount invested in the classic offer $(3,551.79 €>2,789.45 €)$. For the CSP participants, company stocks are the preferred asset $(74.45 \%$ of the participants with an $11,360 €$ average investment), followed by the monetary fund $(64.66 \% ; 6,838 €)$, the diversified fund invested in eurozone bonds $(53.30 \% ; 3,931 €)$, the diversified fund invested in international stocks $(45.37 \% ; 3,626 €)$, and the diversified fund invested in eurozone stocks $(38.73 \% ; 3,281 €)$.

The statistics in Table 5 relate the Sharpe ratios, the returns and the volatility of the individual portfolios to the variables. We focus on the Sharpe ratios. On average, the Sharpe ratios are higher for older employees, women, small-city residents, employees with an intermediate education level (high school and bachelor's degrees), employees who are less wealthy, employees with lower salaries and bonuses, employees with permanent contracts, the most senior employees, and the lowest-ranked employees. Meanwhile, finance experts, as well as commercial, HRM, and administrative staff, have lower Sharpe ratios than those of their colleagues. The statistics regarding wealth, salary, bonus, hierarchical rank, and financial expertise are counterintuitive. In most cases, they are explained by higher portfolio returns (for finance experts and wealthier, higher-paid, and better-ranked employees) compensated by even higher volatility. In other words, the Sharpe ratios of these categories are a consequence of higher returns but riskier portfolios. Such choices can be related to the overconfidence of these categories of employees, who tend to take higher risks that do not necessarily translate into better returns. Table 6 displays the correlation matrix of the variables included in the regressions.

\subsection{Regression analyses}

Tables 7, 8 and 9 report the coefficients of the regressions on the individual Sharpe ratios. For the CSP, ESPP, and both plans, the first and second columns display the probit regression coefficients, and columns 3 to 6 show the OLS regression coefficients. Two sets of independent variables are included in the regressions: demographic and job variables. With respect to the job-related variables, finance experts are financially literate, and HRM staff know the rules of the plan (early withdrawal conditions, for instance). The highest-ranked employees may have better knowledge of the company's future returns. Being a finance expert positively affects the decision to participate in both plans and is positively related to ESPP portfolio efficiency; however, it does not significantly affect the CSP efficiency. When we look at both plans, the probability of participating is higher for financially literate employees, but being 
financially literate is negatively (sig $10 \%$ ) related to the overall Sharpe ratio. These initial results suggest that finance experts behave differently when offered their employer's stocks only than when they have to invest in a plan offering several investment options. Therefore, they may be affected by the "mental accounting of company stock" documented by Benartzi and Thaler (2001), which involves putting company stock into a different asset category from other equities. HRM staff is assumed to have better knowledge of the rules of the plans. These employees also have to advertise the plans and to provide answers to questions about the plans to their colleagues. The HRM dummy is not significantly associated with participation and efficiency of CSP investment. Overall, these employees participate more but do not have significantly higher efficiency. The result regarding HRM staff as having better knowledge of the ESPP plan is consistent with the previous findings of Engelhardt and Madrian (2004) and Rapp and Aubert (2011). Again the different results for the two plans offered suggest a mental accounting of company stock. Previous knowledge of the plan can be related to individual past experience, as measured by the number of years employed. The number of years employed affects the efficiencies of the overall plans and of the CSP but has no significant relation with participation. This variable can be interpreted in two ways. First, the longer an employee works for a company, the higher her specific human capital and the lower her incentive to invest in the company stock. An informed diversification strategy should prevent investment of employees whose human capital is more specific and less transferable. Second, Malmendier and Nagel (2011) find that past experience predicts equity investment. In our case, the company experienced positive past returns over the two previous years. Benartzi (2001) finds that employees tend to excessively extrapolate their company's past returns and link this behavior to the representativeness bias documented by behavioral economics. Our findings validate the two approaches since more experienced employees participate less but have better performance. These employees would secure their past performance by not participating. Our data do not allow for testing the disposition effect, but the lack of significance of the years employed variable can also have some connection with this behavioral bias. Recall that in the French company savings plans, the savings are blocked for five years. Lower participation by more experienced employees may compensate for this legal obligation. Employees with the highest hierarchical rank have better knowledge of the bank's strategy and future returns. The regression coefficients associated with the rank variable display positive signs for ESPP participation and efficiency, indicating that higher-ranked employees participate more in the employer's stock offer and obtain better performance. Conversely, hierarchical rank does not predict participation or better performance in the CSP. These results suggest that higher- 
ranked employees have better information about their company's performance and do not confirm the previous findings of Benartzi (2001) and (Cohen, 2009). Commercial staff are financial advisors to the bank's customers. Being a commercial employee is associated with a higher participation rate in the CSP and both plans but is not related to higher efficiency. Our results in this regard are consistent with those of Calcagno and Monticone (2015) and Hackethal et al. (2012), who investigate the consequences of financial advice on the portfolio choices of bank customers. Calcagno and Monticone (2015) show that bank advisors are not sufficient to alleviate the problem of financial literacy, whereas Hackethal et al. (2012) find that advised customers have a lower risk-return trade-off ratio (measured by the Sharpe ratio). Our results suggest that the bank customer choices documented by these authors may be a consequence of bank advisors who do not make the best choices for their own portfolio.

The competencies of the logistics staff are not specific to the finance industry. The logistics staff dummy is negatively related to participation in the ESPP and is not significantly related to the other dependent variables. Holding an administrative position is positively related to participation in both plans, CSP participation, and better ESPP efficiency. Higher wages and bonuses are related to higher participation rates in both plans but not to better Sharpe ratios. Salary positively affects ESPP participation and efficiency, whereas bonuses are negatively associated with both variables. Our proxy of wealth is positively related to participation in the ESPP and the CSP. This result is in line with the Arrow-Pratt absolute risk aversion being a decreasing function of wealth. As their wealth increases, employees tend to invest more in risky assets. Employees with a permanent contract participate less frequently. Temporary employees are eligible after six months, and they can withdraw the money invested in the plans at the end of their contract while benefiting from tax exemptions. This rule creates a windfall for temporary employees. Salary, bonus, wealth and permanent contract capture the liquidity constraints faced by employees. These variables were included in previous works investigating ESPP and company-based savings (Degeorge et al., 2004, Engelhardt and Madrian, 2004, Rapp and Aubert, 2011; Babenko and Sen, 2014). Our results are in line with previous findings regarding participation in these plans, and we provide new evidence regarding portfolio efficiency.

Most of the regression coefficients associated with the demographic variables are significant, but we document different results depending on the type of plan. With the exception of wealth, the signs of the regression coefficients are often different for the two steps of the Heckman regressions. For the CSP regressions and for both steps of the regressions, the coefficients related to $a g e^{2}$, gender and education level are positive, whereas they are negative 
for the ESPP regressions. The age coefficients are negative for the CSP and positive for the ESPP. These signs correspond to an inverted U-shaped relation for the ESPP and a U-shaped relation for the CSP. The first result is consistent with previous findings regarding ESPP investment (Degeorge et al., 2004; Engelhardt and Madrian, 2004; Rapp and Aubert, 2011; Babenko and Sen, 2014). Place of residence is significant only for participation in the ESPP. These opposite results reveal the different natures of the two plans. CSP offers various investment options, including company stock, and ESPP offers only company stock. In addition to this difference, ESPP is a one-shot plan, providing the opportunity to invest in the company only once. By contrast, CSP is an ongoing plan that allows continuous investment.

\subsection{Additional tests and robustness checks}

In addition to the regressions of the Sharpe ratios on the independent variables, we perform regressions of the components of the Sharpe ratio, i.e., the return (fourth column of Tables 7. 8 and 9) and volatility (fifth column of Tables 7, 8, and 9), and for another efficiency measure - the information ratio (sixth column of Tables 7, 8 and 9). The information ratio is an alternative portfolio efficiency measure of risk-adjusted returns in relation to a benchmark. As a benchmark, we use the three-monthly French state treasury bills as a proxy for risk-free return because, first, we have previously documented the high concentration of the employees' portfolios in the money fund. Second, Goodwin (1998) advocates the use of the risk-free rate as a benchmark and regard the risk-free rate as the return provided by the passive portion of the investor's portfolio.

We focus on the second step of the Heckman regressions because the probit regression coefficients remain the same. In Table 7 , the variables significantly associated with the returns of both plans are age $(+)$ age $^{2}(-)$, gender $(+)$, place of residence $(+)$, education level $(-)$, permanent contract $(+)$, hierarchical rank $(+)$, and administrative staff $(+)$. For the CSP returns, the variables associated with the returns are age ${ }^{2}(+)$, gender $(-)$, salary $(-)$, finance expert $(+)$, and logistics staff $(-)$. For the ESPP returns, the significant coefficients are age $(+)$ age $^{2}(-)$, gender $(-)$, education level $(-)$, salary $(+)$, hierarchical rank $(+)$, commercial staff $(+)$, and HRM staff $(+)$. The regression coefficients of volatility are displayed in the fifth columns of Tables 7, 8 and 9. For both plans, variables significantly associated with volatility are age $(+)$ age $^{2}(-)$, gender $(-)$, place of residence $(+)$, education level $(+)$, permanent contract (-), hierarchical rank (+), and administrative staff (-). For the CSP volatility, the significant factors are age ${ }^{2}(+)$, gender $(-)$, salary (-), finance expert $(+)$, and logistics staff (-). The significant coefficients for the ESPP volatility are age $(+)$, age $^{2}(-)$, gender $(-)$, education 
level $(-)$, salary $(+)$, hierarchical rank $(+)$, commercial staff $(+)$, and HRM staff $(+)$.

We also run regressions on the information ratio; the results are presented in the sixth columns of Tables 7, 8 and 9. Again, we focus on OLS regressions and compare the results to those of the Sharpe ratio regressions. We find different results for most of the variables for both plans: age ${ }^{2}$, gender, education level, years employed, hierarchical rank, finance expert, commercial staff, and administrative staff. The signs change for age ${ }^{2}$, gender, education level, years employed, and hierarchical rank. When we consider the two plans offered to the employees, we note that most of these diverging results are due to differences reported for the CSP. Indeed, the regression results of the ESPP information ratio remain the same. Recall that the information ratio takes the risk-free return as a benchmark and that the CSP contains a monetary fund. The presence of such an option affects the results.

We previously identified the presence of outliers due to the construction of the Sharpe ratios. Very large numerator values of excess returns and very low denominator values of volatility produce these outliers. The regression results presented in Tables 7, 8 and 9 do not account for these outliers. As an additional robustness check, we rerun the regressions for all the observations and using a robust estimator. The coefficients of the participation regression in both plans remain the same, and we find different significance levels only for the second step of the OLS regression.

\section{Discussion}

We investigate the risk return determinants of a sample of bank employees in their company savings plans. We first find that the determinants differ depending on the type of plan offered: the ESPP and the CSP. The variables affecting both participation and portfolio efficiency are not the same. These contrasting results reveal the very different nature of the two plans. CSP offers various investment options, including company stock, and ESPP offers only company stock. In addition to this difference, ESPP is a one-shot plan that provides the opportunity to invest in the company only once. By contrast, CSP is an ongoing plan that allows continuous investment. Our results suggest that these differences are driven by the mental accounting of company stock. Employees place their employer's stock in a category separate from that of other assets and consequently optimize their savings separately.

Another important result of our analyses is that better-informed employees do not necessarily have better portfolio efficiency. Again, this result depends on the plan investigated. We measure expertise in terms of information held by the employees with three variables, assuming that finance experts have better knowledge of financial markets, that HRM staff members 
have better knowledge of the administrative functioning of the plan, and that higher-ranked employees have better information about the company's future performance. For this latter category of employees, private information may affect their willingness to invest in company stock, either through the ESPP or the CSP fund that is invested mainly in company stock. Being a finance expert positively affects the decision to participate in both plans, is positively related to ESPP portfolio efficiency and does not affect CSP efficiency. HRM employees participate significantly more frequently in the ESPP than do their colleagues, and they have better ESPP efficiency. Their participation in the CSP and the efficiency of their investment in the CSP are not significantly higher than those of other employees. Higher-ranked bank employees participate more frequently and obtain better efficiency for the ESPP, a plan that is entirely invested in company stock. The portfolio efficiency of higher-ranked employees is lower for the CSP. When we take a closer look at the components of the Sharpe ratios (i.e., returns and volatility), we note that these results are a consequence of the higher returns and higher volatility of the higher-ranked employees and HRM staff in the ESPP and of the higher returns and higher volatility of the finance experts in the CSP. These results are consistent with Bianchi (2018), who finds that more literate households hold riskier positions when expected returns are higher.

Our analysis has several limitations that may restrict the interpretation of the results. First, the number of assets offered by the company in the ESPP and CSP plans does not fully reflect all investment possibilities available in the financial markets. Employees may have better alternative options outside the company savings plans. In fact, our study observes employee wealth only within the plans offered by their company, and our wealth variable proxy does not capture the actual wealth composition. Consequently, since only a fraction of the employees' portfolios is observed, it is difficult to assess the overall portfolio efficiency of the employees based on our findings. We do not measure employees' wealth outside the CSP and ESPP, such as real estate property or net debt. We use a cross-sectional dataset of a sample of employees at a given point in time that does not measure portfolio dynamics and rebalancing. Madrian and Shea (2001) suggest that portfolio dynamics within company-based savings are very low and subject to inertia. Bianchi (2018) finds that financially literate individuals actively rebalance their portfolio over time and maintain a constant risk exposure. The stock price of the company we study experiences positive returns, as reported in Table 2 . According to Malmendier and Nagel (2011), investors who have experienced low returns in the past are less likely to invest in risky assets and have higher risk aversion. Benartzi (2001) notes that returns in the past affect investment in company stock in 401(k) plans. He states that 
this extrapolation of past returns is an example of the representativeness effect documented by behavioral economics. Lusardi and Mitchell (2014) review several variables affecting retail investment that we do not include in our regression analysis, i.e., parental status, religion, political opinions, and being an immigrant. Other omitted variables documented by the household finance literature include specific financial education, rational expectations, ambiguity and loss aversion. Finally, we use French data, and according to Arrondel et al. (2016), France has some idiosyncratic features within the eurozone area. The share of households owning safe (risky) assets is higher (lower) than the eurozone average. Another specificity is that French citizens have less incentive to invest in financial literacy than do citizens of other countries with less generous social security systems (Jappelli and Padula, 2013).

The work of Richard Thaler has strongly influenced research on retail investors' behavior, both theoretically and empirically. From a theoretical perspective, Thaler (1985) develops the notion of mental accounting, which is very important for understanding company-based savings. One application of mental accounting is the behavioral life-cycle hypothesis (Shefrin and Thaler, 1988, 2004), which posits that people mentally frame assets as belonging to either current income, current wealth or future income. This cognitive phenomenon consists of psychologically separating these "accounts" and considering them as non-fungible. As a consequence, the marginal propensity to consume from each account is different. Mental accounting affects company-based savings at two levels. First, the mental accounting of company stocks (Benartzi and Thaler, 2001) consists of employees considering company stocks as a separate asset. The company that provided the data offers ESPP and company stocks in the CSP. Second, the mental accounting of company stocks is very likely to affect the employees, but the mental accounting may be important at the level of overall company savings since it is not clear whether employees consider company savings separately from other components of their wealth. On the theoretical side, Thaler challenges the premise of economic theory that people choose by optimizing. His research has contributed to the inclusion of behavioral biases or "supposedly irrelevant factors" (Thaler, 2015). Although the influence of such factors is not tested directly, they may affect the behavior of the bank employees, including those who have better knowledge of financial securities. In addition to mental accounting, these factors include the framing effect, the role of past experience, the default heuristics, inertia, overconfidence and the disposition effect. On the empirical side, several joint papers of Thaler and Benartzi contribute to a better understanding of company-based savings. Naïve diversification and mental accounting were documented empirically and are now used to help people to make better decisions for their retirement, for example, the SMarT plan (Thaler 
and Benartzi, 2004).

\section{Conclusion}

In this paper, we investigate the portfolio efficiency of bank employees. Some of the bank employees are trained to understand financial markets, some know the administrative functioning of the plans, and some are likely to hold private information about the company's future returns. We do not have access to all the components of the employees' overall wealth, but even these well-informed and trained employees do not appear to adopt efficient investment strategies.

Our results suggest that financial expertise and knowledge of the plans are related to participation in the plans offered by the company, confirming our first hypothesis. Financial expertise is related to better ESPP individual portfolio performance but not to better overall and CSP performance. Our second hypothesis is validated only for ESPP investment. For both plans offered, participation is more likely among most of the job categories that include finance experts, female employees, more educated employees and less financially constrained employees. We find evidence of the mental accounting of company stock highlighted by Benartzi and Thaler (2001).

We also suggest that financially literate investors are affected by behavioral biases such as mental accounting. This result is in line with the previous findings of Boolell-Gunesh et al. (2009, 2012) and Broihanne et al. (2014), who showed that both sophisticated investors and finance professionals are also subject to behavioral biases, such as the disposition effect, overconfidence and optimism.

\section{References}

Arrondel, L., Bartiloro, L., Fessler, P., Lindner, P., Mathä, T., Rampazzi, C., Savignac, F., Schmidt, T., Schürz, M., and Vermeulen, P. (2016). How do households allocate their assets? stylized facts from the eurosystem household finance and consumption survey. 12:129-220.

Babenko, I. and Sen, R. (2014). Money left on the table: An analysis of participation in employee stock purchase plans. Review of Financial Studies, 12(27):3658-3698.

Benartzi, S. (2001). Excessive Extrapolation and the Allocation of 401(k) Accounts to Company Stock. The Journal of Finance, 56(5):1747-1764. 
Benartzi, S. and Thaler, R. H. (1999). Risk Aversion or Myopia? Choices in Repeated Gambles and Retirement Investments. Management Science, 45(3):364-381.

Benartzi, S. and Thaler, R. H. (2001). Naive diversification strategies in defined contribution saving plans. American Economic Review, pages 91-79.

Benartzi, S. and Thaler, R. H. (2002). How Much Is Investor Autonomy Worth? The Journal of Finance, 57(4):1593-1616.

Benartzi, S., Thaler, R. H., Utkus, S. P., and Sunstein, C. R. (2007). The law and economics of company stock in $401(\mathrm{k})$ plans. Journal of law and economics, 50:45-79.

Benzoni, L., Collin-Dufresne, P., and Goldstein, R. S. (2007). Portfolio Choice over the LifeCycle when the Stock and Labor Markets Are Cointegrated. The Journal of Finance, $62(5): 2123-2167$.

Bhamra, H. and Uppal, R. (2016). Does Household Finance Matter? Small Financial Errors with Large Social Costs. SSRN Scholarly Paper ID 2722803, Social Science Research Network, Rochester, NY.

Bianchi, M. (2018). Financial literacy and portfolio dynamics. The Journal of Finance, $73(2): 831-859$.

Blume, M. E. and Friend, I. (1975). The Asset Structure of Individual Portfolios and Some Implications for Utility Functions. The Journal of Finance, 30(2):585-603.

Boolell-Gunesh, S., Broihanne, M.-H., and Merli, M. (2012). Sophistication of individual investors and disposition effect dynamics. Finance, 33(1):9-37.

Boolell-Gunesh, S., Merli, M., and Broihanne, M.-H. (2009). Disposition effect, investor sophistication and taxes: Some french specificities. Finance, 30(1):51 - 78 .

Broihanne, M., Merli, M., and Roger, P. (2014). Overconfidence, risk perception and the risk-taking behavior of finance professionals. Finance Research Letters, 11(2):64-73.

Brunnermeier, M. K. and Nagel, S. (2008). Do Wealth Fluctuations Generate Time-Varying Risk Aversion? Micro-Evidence on Individuals' Asset Allocation. The American Economic Review, 98(3):713-736.

Calcagno, R. and Monticone, C. (2015). Financial literacy and the demand for financial advice. Journal of Banking E Finance, 50(Supplement C):363-380. 
Calvet, L. E., Campbell, J. Y., and Sodini, P. (2009). Measuring the Financial Sophistication of Households. The American Economic Review, 99(2):393-398.

Calvet, L. E. and Sodini, P. (2014). Twin Picks: Disentangling the Determinants of RiskTaking in Household Portfolios. The Journal of Finance, 69(2):867-906.

Campbell, J. Y. (2006). Household Finance. The Journal of Finance, 61(4):1553-1604.

Chiappori, P.-A. and Paiella, M. (2011). Relative Risk Aversion Is Constant: Evidence From Panel Data. Journal of the European Economic Association, 9(6):1021-1052.

Choi, J., Laibson, D., Madrian, B., and Metrick, A. (2004). Employees' Investment Decisions about Company Stock. SSRN Scholarly Paper ID 562513, Social Science Research Network, Rochester, NY.

Cocco, J. F. (2005). Consumption and Portfolio Choice over the Life Cycle. Review of Financial Studies, 18(2):491-533.

Cohen, L. (2009). Loyalty-Based Portfolio Choice. The Review of Financial Studies, 22(3):1213-1245.

Croson, R. and Gneezy, U. (2009). Gender Differences in Preferences. Journal of Economic Literature, 47(2):448-474.

D’ Hondt, C. and Roger, P. (2017). Investor sentiment and stock return predictability: The power of ignorance. Finance, 38(2):7-37.

Degeorge, F., Jenter, D., Moel, A., and Tufano, P. (2004). Selling company shares to reluctant employees: France Telecom's experience. Journal of Financial Economics, 71(1):169-202.

Dohmen, T., Falk, A., Huffman, D., Sunde, U., Schupp, J., and Wagner, G. G. (2011). Individual Risk Attitudes: Measurement, Determinants, and Behavioral Consequences. Journal of the European Economic Association, 9(3):522-550.

Engelhardt, G. V. and Madrian, B. C. (2004). Employee Stock Purchase Plans. National Tax Journal, 57(2, Part 2):385-406.

Feng, L. and S. Seasholes, M. (2005). Do investor sophistication and trading experience eliminate behavioral biases in financial markets? Review of Finance, 9(3):305-351.

Flavin, M. and Yamashita, T. (2002). Owner-Occupied Housing and the Composition of the Household Portfolio. American Economic Review, 92(1):345-362. 
Goetzmann, W. N. and Kumar, A. (2008). Equity Portfolio Diversification. Review of Finance, pages $433-463$.

Goodwin, T. H. (1998). The information ratio. Financial Analysts Journal, 54(4):34-43.

Guiso, L. and Sodini, P. (2013). Household Finance: An Emerging Field. Handbook of the Economics of Finance, 2:1397-1532.

Hackethal, A., Haliassos, M., and Jappelli, T. (2012). Financial advisors: A case of babysitters? Journal of Banking 83 Finance, 36(2):509-524.

Haliassos, M. and Bertaut, C. C. (1995). Why do so Few Hold Stocks? The Economic Journal, 105(432):1110-1129.

Heaton, J. and Lucas, D. (2000). Portfolio Choice and Asset Prices: The Importance of Entrepreneurial Risk. The Journal of Finance, 55(3):1163-1198.

Heckman, J. J. (1979). Sample selection bias as a specification error. Econometrica, 47(1):153161.

Huberman, G. (2001). Familiarity Breeds Investment. The Review of Financial Studies, 14(3):659-680.

Jappelli, T. and Padula, M. (2013). Investment in financial literacy and saving decisions. Journal of Banking \& Finance, 37(8):2779-2792.

Lusardi, A. and Mitchell, O. S. (2014). The Economic Importance of Financial Literacy: Theory and Evidence. Journal of Economic Literature, 52(1):5-44.

Madrian, B. C. and Shea, D. F. (2001). The Power of Suggestion: Inertia in 401(k) Participation and Savings Behavior. The Quarterly Journal of Economics, 116(4):1149-1187.

Malmendier, U. and Nagel, S. (2011). Depression Babies: Do Macroeconomic Experiences Affect Risk Taking?*. The Quarterly Journal of Economics, 126(1):373-416.

Merton, R. C. (1969). Lifetime Portfolio Selection under Uncertainty: The Continuous-Time Case. The Review of Economics and Statistics, 51(3):247-257.

Meulbroek, L. (2005). Company Stock in Pension Plans: How Costly Is It? The Journal of Law and Economics, 48(2):443-474. 
Mitchell, O. S. and Utkus, S. P. (2003). Company stock and retirement plan diversification. In: Smetters, O.S.M.a.K. (Ed.), The Pension Challenge: Risk Transfers and Retirement Income Security. Oxford University Press, Oxford:33-70.

Ramaswamy, K. (2003). Company stock and pension plan diversification. in: Mitchell, O., Smetters, K. (Eds.), The pension challenge: risk transfers and retirement income security. Oxford University Press, Philadelphia, pages 71-88.

Rapp, T. and Aubert, N. (2011). Bank Employee Incentives and Stock Purchase Plans Participation. Journal of Financial Services Research, 40(3):185-203.

Roger, P. (2014). The 99\% market sentiment index. Finance, 35(3):53-96.

Shefrin, H. and Statman, M. (1985). The disposition to sell winners too early and ride losers too long: Theory and evidence. The Journal of Finance, 40(3):777-790.

Shefrin, H. and Thaler, R. H. (2004). Mental accounting, saving, and self-control. Advances in behavioral economics, pages 395-428.

Shefrin, H. M. and Thaler, R. H. (1988). The behavioral life-cycle hypothesis. Economic Inquiry, (26):609-643.

Storesletten, K., Telmer, C. I., and Yaron, A. (2007). Asset pricing with idiosyncratic risk and overlapping generations. Review of Economic Dynamics, 10(4):519-548.

Thaler, R. (1980). Toward a positive theory of consumer choice. Journal of Economic Behavior Es Organization, 1:39-60.

Thaler, R. (1985). Mental accounting and consumer choice. Marketing Science, 4:199-214.

Thaler, R. H. (2015). Misbehaving: The making of behavioral economics. WW Norton \& Company.

Thaler, R. H. and Benartzi, S. (2004). Save more tomorrow: Using behavioral economics to increase employee saving. Journal of Political Economy, (112):164-187.

Von Neumann, J. and Morgenstern, O. (2007). Theory of Games and Economic Behavior. Princeton University Press.

Wooldridge, J. M., editor (2015). Introductory econometrics: A modern approach. Cengage Learning. 


\section{Appendices}

Table 1: Description of the variables included in the analyses

DEMOGRAPHIC VARIABLES

\begin{tabular}{|c|c|c|}
\hline Variables' names & Description & Source \\
\hline Age & Age is the employee's age in years. & Company's data \\
\hline Gender & $\begin{array}{l}\text { Gender takes the value of } 1 \text { if the employee is a } \\
\text { women and } 0 \text { otherwise. }\end{array}$ & Company's data \\
\hline $\begin{array}{l}\text { Place of resi- } \\
\text { dence }\end{array}$ & $\begin{array}{l}\text { Place of residence takes the value of } 1 \text { if the employee } \\
\text { lives in a large city. } \\
\text { and } 0 \text { otherwise }\end{array}$ & Company's data \\
\hline $\begin{array}{l}\text { Education } \\
\text { level }\end{array}$ & $\begin{array}{l}\text { Education level takes the following values according } \\
\text { to the education level: 1: secondary school degree } \\
\text { | 2: high school diploma | } 3 \text { : bachelor's degree | 4: } \\
\text { master's degree | 5: master's degree and higher. }\end{array}$ & Company's data \\
\hline Wealth & Wealth is a proxy of employee's overall wealth. & $\begin{array}{l}\text { INSEE localised tax } \\
\text { revenues system }\end{array}$ \\
\hline \multicolumn{3}{|c|}{ JOB CHARACTERISTICS VARIABLES } \\
\hline Variables' names & Description & Source \\
\hline Salary & Salary is the employee's gross annual salary in euros. & Company's data \\
\hline Bonus & $\begin{array}{l}\text { Bonus is the annual bonus amount granted to the } \\
\text { employee in euros. }\end{array}$ & Company's data \\
\hline $\begin{array}{l}\text { Permanent } \\
\text { contract }\end{array}$ & $\begin{array}{l}\text { Permanent contract takes the value of } 1 \text { if the em- } \\
\text { ployee has a permanent contract and } 0 \text { otherwise. }\end{array}$ & Company's data \\
\hline $\begin{array}{l}\text { Years } \quad \text { em- } \\
\text { ployed }\end{array}$ & $\begin{array}{l}\text { Years employed is the number of years the employee } \\
\text { has worked for the bank. }\end{array}$ & Company's data \\
\hline $\begin{array}{l}\text { Hierarchical } \\
\text { rank }\end{array}$ & $\begin{array}{l}\text { Hierarchical rank is an internal hierarchical ranking } \\
\text { system ranging from } 1 \text { (lowest) to } 12 \text { (highest). }\end{array}$ & Company's data \\
\hline $\begin{array}{l}\text { Finance ex- } \\
\text { pert }\end{array}$ & $\begin{array}{l}\text { Finance expert takes the value of } 1 \text { if the employee } \\
\text { is a finance expert and } 0 \text { otherwise. }\end{array}$ & Company's data \\
\hline $\begin{array}{l}\text { Commercial } \\
\text { staff }\end{array}$ & $\begin{array}{l}\text { Commercial staff takes the value of } 1 \text { if the employee } \\
\text { interacts with the bank's customers and } 0 \text { otherwise. }\end{array}$ & Company's data \\
\hline HRM staff & $\begin{array}{l}\text { HRM staff takes the value of } 1 \text { if the employee is part } \\
\text { of the HRM staff and } 0 \text { otherwise. }\end{array}$ & Company's data \\
\hline Logistics staff & $\begin{array}{l}\text { Logistics staff takes the value of } 1 \text { if the employee is } \\
\text { part of the logistics staff and } 0 \text { otherwise. }\end{array}$ & Company's data \\
\hline $\begin{array}{l}\text { Administrative } \\
\text { staff }\end{array}$ & $\begin{array}{l}\text { Administrative staff takes the value of } 1 \text { if the em- } \\
\text { ployee is part of the administrative staff and } 0 \text { oth- } \\
\text { erwise. }\end{array}$ & Company's data \\
\hline Other staff & $\begin{array}{l}\text { Other staff takes the value of } 1 \text { if the employee cannot } \\
\text { be identified as part of other employment dummies. }\end{array}$ & Company's data \\
\hline
\end{tabular}



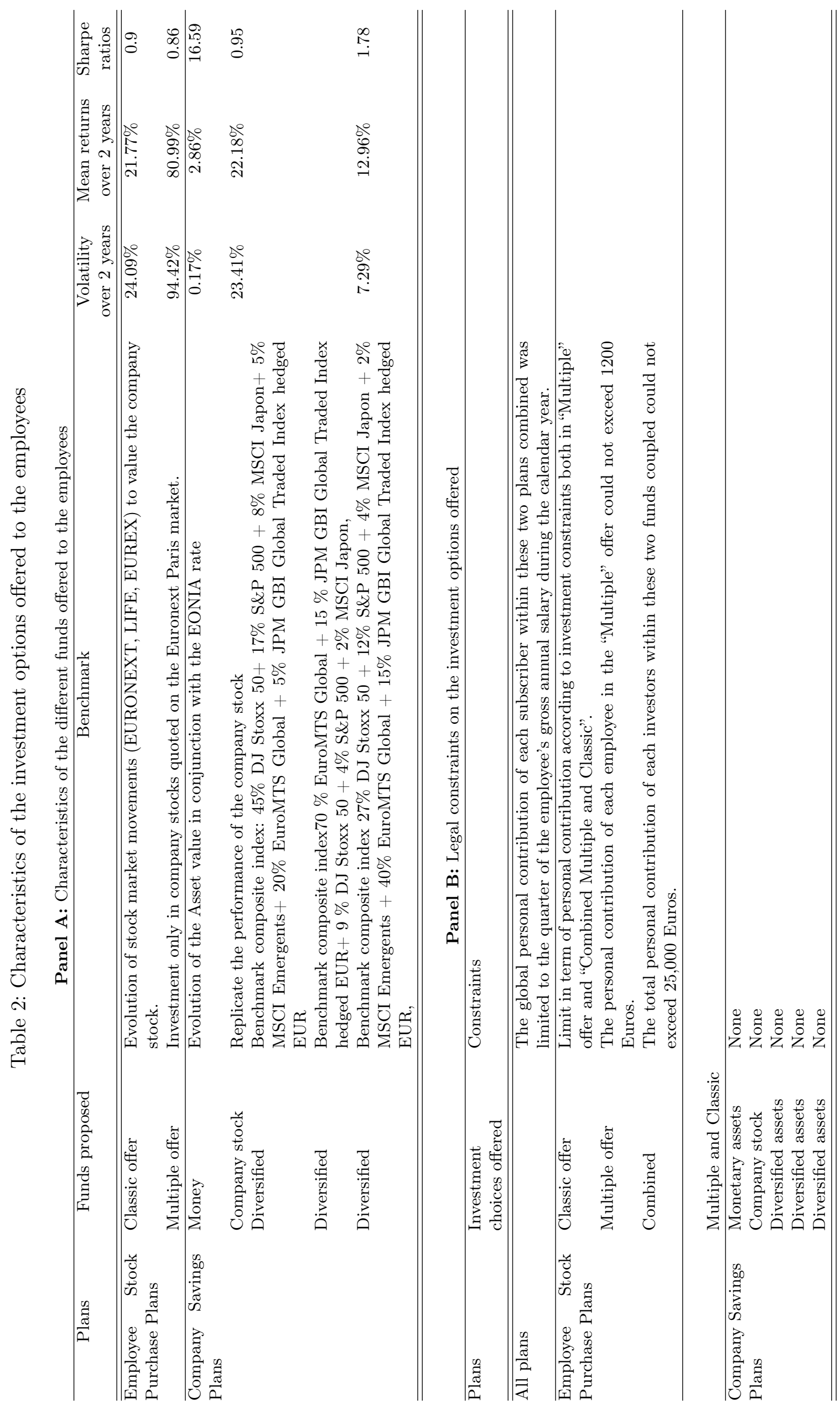


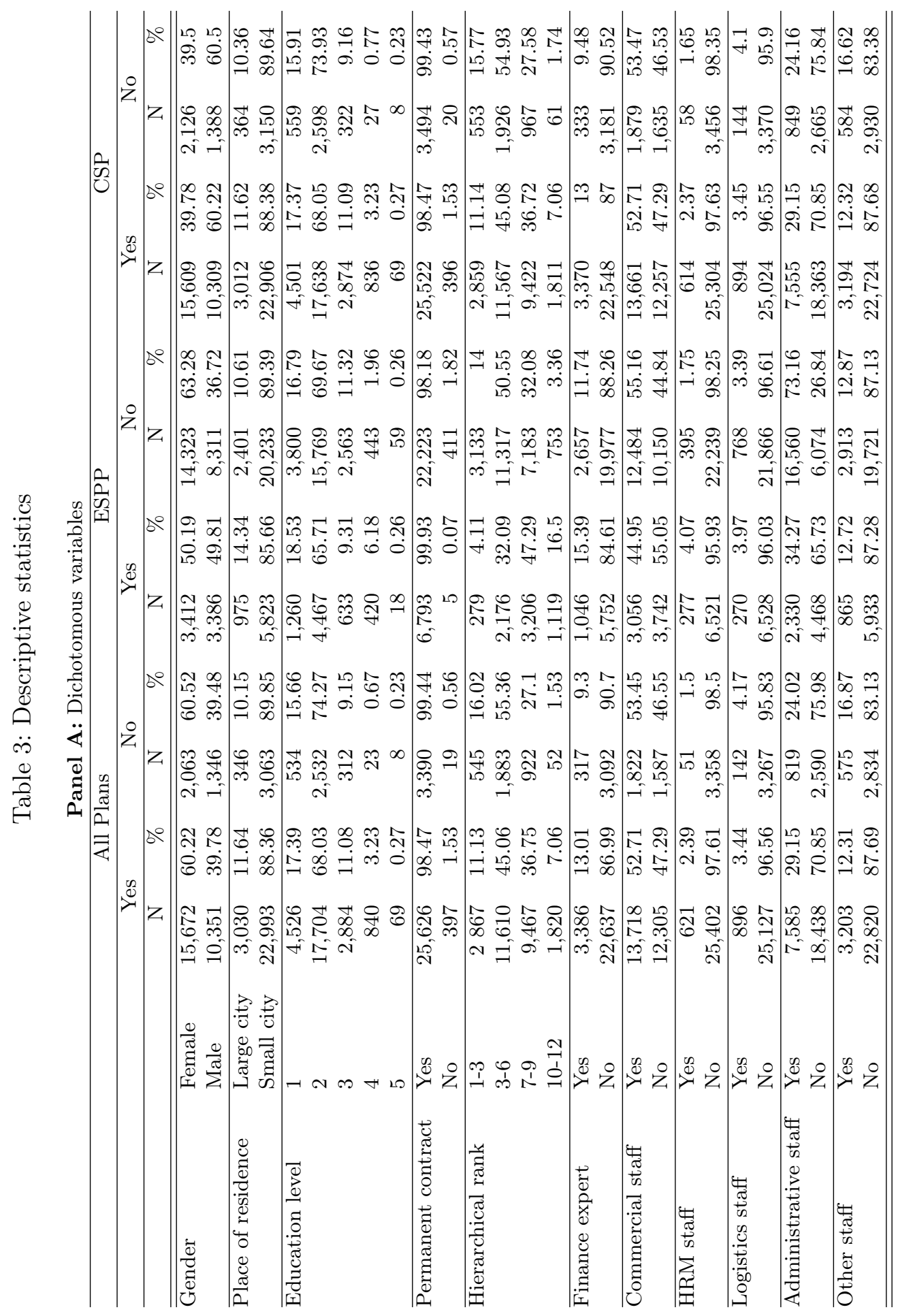


Panel B: Continuous variables

All Plans

\begin{tabular}{|c|c|c|c|c|c|c|c|c|c|c|}
\hline Participation & & & Yes & & & & & No & & \\
\hline & $\mathrm{N}$ & Mean & Min & $\operatorname{Max}$ & SD & $\mathrm{N}$ & Mean & Min & $\operatorname{Max}$ & SD \\
\hline Age & 26,023 & 46.40 & 19 & 65 & 10.77 & 3,409 & 46.94 & 20 & 65 & 10.39 \\
\hline Wealth & 24,607 & $35,750.40$ & $18,386.56$ & $94,954.64$ & $8,688.70$ & 3173 & $34,710.12$ & $18,522.27$ & $87,860.09$ & $8,170.08$ \\
\hline Salary & 26,023 & $29,817.70$ & 8,688 & 390,000 & $12,823.77$ & 3,409 & $26,079.43$ & 8,700 & 100,000 & $6,154.77$ \\
\hline Bonus & 26,023 & $1,550.97$ & 0 & 650000 & $5,945.87$ & 3,409 & 641.91 & 0 & 34,000 & $1,336.86$ \\
\hline Years employed & 26,023 & 25.28 & 0 & 45 & 12.46 & 3,409 & 26.12 & 0 & 46 & 11.96 \\
\hline Portfolio's return & 26,023 & $9.51 \%$ & $0.00 \%$ & $50.62 \%$ & $6.53 \%$ & 3,409 & - & - & - & - \\
\hline Portfolio's vol. & 26,023 & $9.95 \%$ & $0.00 \%$ & $94.37 \%$ & $10.23 \%$ & 3,409 & - & - & - & - \\
\hline Portfolio's SR & 26,023 & 0.88 & -0.88 & 1.78 & 0.39 & 3409 & - & - & - & - \\
\hline $\begin{array}{l}\text { Average amount } \\
\text { invested per } \\
\text { job category }\end{array}$ & 26,023 & $16,727.76$ & $13,552.59$ & $25,993.30$ & $3,573.52$ & 3409 & $16,502.45$ & $13,552.59$ & $25,993.30$ & $3,377.61$ \\
\hline
\end{tabular}

ESPP

\begin{tabular}{|c|c|c|c|c|c|c|c|c|c|c|}
\hline Participation & & & Yes & & & & & No & & \\
\hline & $\mathrm{N}$ & Mean & Min & Max & SD & $\mathrm{N}$ & Mean & Min & Max & $\mathrm{SD}$ \\
\hline Age & 6,798 & 48.13 & 21 & 65 & 8.92 & 22,634 & 45.96 & 19 & 65 & 11.17 \\
\hline Wealth & 6,458 & $37,081.17$ & $18,386.56$ & $87,860.09$ & $9,255.58$ & 21,322 & $35,192.53$ & $18,522.27$ & $94,954.64$ & $8,391.99$ \\
\hline Salary & 6,798 & $36,096.79$ & 14,904 & 382,860 & $18,390.63$ & 22,634 & $27,368.77$ & 8,688 & 390,000 & $8,801.80$ \\
\hline Bonus & 6,798 & $3,029.36$ & 0 & 300,000 & $7,717.61$ & 22,634 & 970.03 & 0 & 650,000 & $4,707.39$ \\
\hline Years employed & 6,798 & 26.54 & 2 & 44 & 11.16 & 22,634 & 25.03 & 0 & 46 & 12.73 \\
\hline Portfolio's return & 6,798 & $1.91 \%$ & $0.00 \%$ & $50.62 \%$ & $5.93 \%$ & 22,634 & - & - & - & - \\
\hline Portfolio's vol. & 6,798 & $3.17 \%$ & $0.00 \%$ & $94.37 \%$ & $9.96 \%$ & 22,634 & - & - & - & - \\
\hline Portfolio's SR & 6,798 & 0.02 & -321.44 & 0.67 & 4.25 & 22,634 & - & - & - & - \\
\hline $\begin{array}{l}\text { Average amount } \\
\text { invested per } \\
\text { job category }\end{array}$ & 6,798 & $17,362.02$ & $13,552.59$ & $25,993.30$ & $3,734.85$ & 22,634 & $16,503.32$ & $13,552.59$ & $25,993.30$ & $3,470.93$ \\
\hline
\end{tabular}

\section{CSP}

\begin{tabular}{|c|c|c|c|c|c|c|c|c|c|c|}
\hline & $\mathrm{N}$ & Mean & Min & $\operatorname{Max}$ & SD & $\mathrm{N}$ & Mean & Min & Max & SD \\
\hline Wealth & 24,509 & $3 \bar{c} 35,756.81$ & $18,386.56$ & $94,954.64$ & $8,695.65$ & 3,271 & $34,693.27$ & 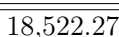 & $87,860.09$ & $8,126.40$ \\
\hline Salary & 25,918 & $29,811.49$ & 8,700 & 390,000 & 12,824 & 3,514 & $26,236.93$ & 8,688 & 100,000 & $6,508.07$ \\
\hline$\overline{\text { Bonus }}$ & 25,918 & $1,549.63$ & 0 & 650,000 & $5,953.44$ & 3,514 & 679.01 & 0 & 34,000 & $1,472.00$ \\
\hline Years employed & 25,918 & 25.29 & 0 & 45 & 12.45 & 3,514 & 26.04 & 0 & 46 & 12.00 \\
\hline Portfolio's return & 25,918 & $7.60 \%$ & $0.00 \%$ & $14.83 \%$ & $4.00 \%$ & 3,514 & - & - & - & - \\
\hline Portfolio's vol. & 25,918 & $7.48 \%$ & $0.00 \%$ & $23.39 \%$ & $5.66 \%$ & 3,514 & - & - & - & - \\
\hline Portfolio's SR & 25,918 & -24.47 & -594197.44 & 1.78 & $3,705.92$ & 0 & - & - & - & - \\
\hline $\begin{array}{l}\text { Average amount } \\
\text { invested per } \\
\text { job category }\end{array}$ & 25,918 & $16,726.88$ & $13,552.59$ & $25,993.3$ & $3,571.584$ & 3,514 & $16,515.60$ & $13,552.59$ & $25,993.30$ & $3,399.33$ \\
\hline
\end{tabular}


Table 4: Participation rates and amount invested by investment options Panel A: Participation rates

\begin{tabular}{llllrrr}
\hline & & \multicolumn{2}{c}{ Participation } & \multicolumn{2}{c}{ Non Participation } & Total \\
& & $\mathrm{N}$ & $\%$ & \multicolumn{1}{c}{$\mathrm{N}$} & \multicolumn{1}{c}{$\%$} & \multicolumn{1}{c}{$\mathrm{N}$} \\
\hline \hline ESPP & Classic offer & 3,368 & 49.54 & 3,430 & 50.46 & 6,798 \\
& Multiple offer & 5,695 & 83.77 & 1,103 & 16.23 & 6,798 \\
\hline CSP & Monetary assets & 16,758 & 64.66 & 9,160 & 35.34 & 25,918 \\
& Company stocks & 19,297 & 74.45 & 6,621 & 25.55 & 25,918 \\
& Diversified Asset 8651 & 10,037 & 38.73 & 15,881 & 61.27 & 25,918 \\
& Diversified Asset 8652 & 13,814 & 53.30 & 12,104 & 46.70 & 25,918 \\
& Diversified Asset 8653 & 11,760 & 45.37 & 14,158 & 54.63 & 25,918 \\
\hline \hline
\end{tabular}

Panel B: Amount invested

\begin{tabular}{llrrrrr}
\hline & & $\mathrm{N}$ & Mean & Min & Max & SD \\
\hline \hline ESPP & Classic offer & 3,368 & 3551.79 & 5.38 & $44,751.45$ & $4,157.69$ \\
& Multiple offer & 5,695 & 2789.45 & 47.66 & $5,719.57$ & $1,510.02$ \\
\hline CSP & Monetary assets & 16,758 & $6,838.97$ & .11 & $155,086.4$ & $9,597.12$ \\
& Company stocks & 19,297 & $11,360.23$ & .01 & 454,515 & $17,698.03$ \\
& Diversified Asset 8651 & 10,037 & $3,281.74$ & .01 & $113,036.4$ & $5,529.79$ \\
& Diversified Asset 8652 & 13,814 & $3,931.33$ & .02 & $115,907.3$ & $6,567.11$ \\
& Diversified Asset 8653 & 11,760 & $3,626.09$ & .06 & $140,439.7$ & $5,759.29$ \\
\hline \hline
\end{tabular}




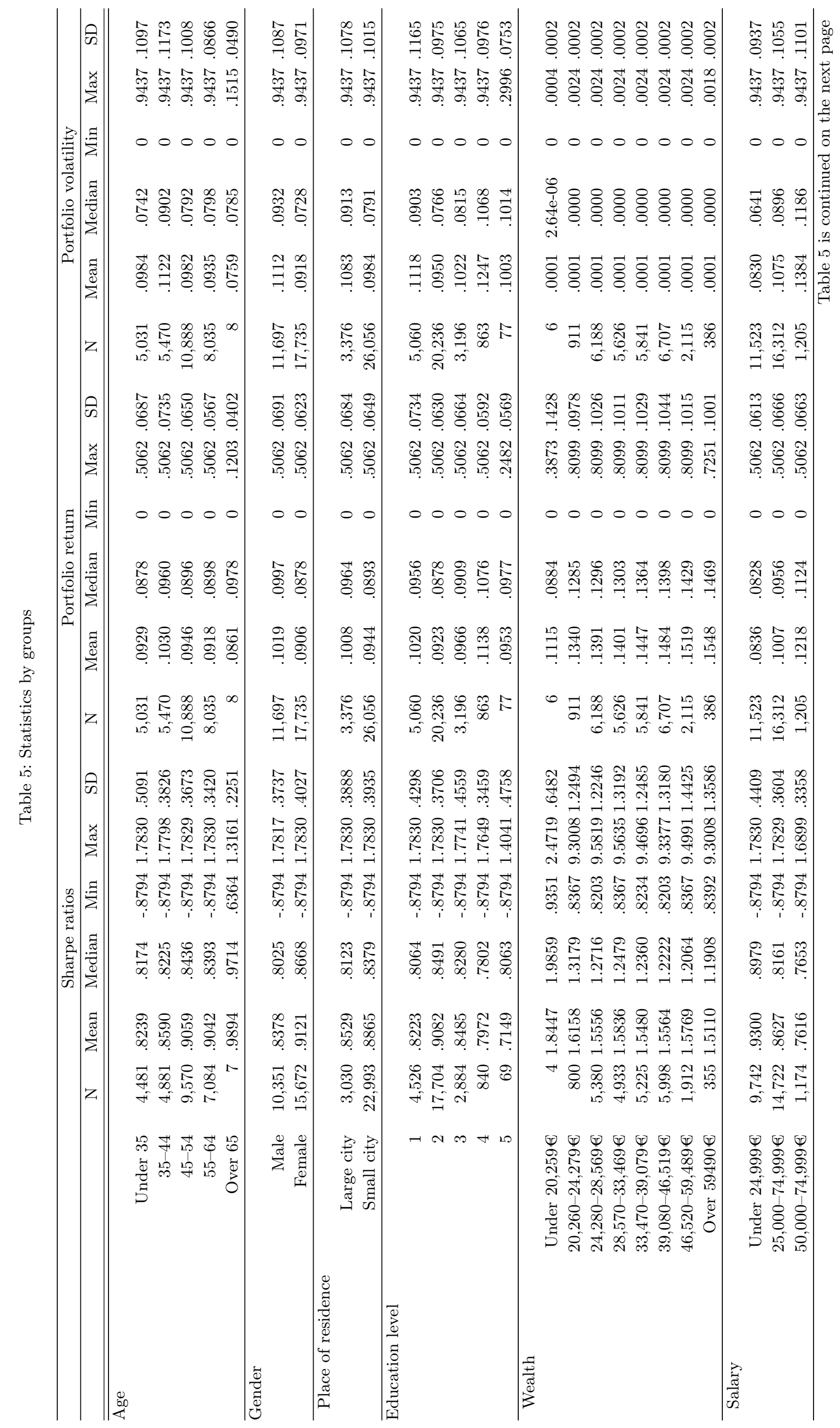




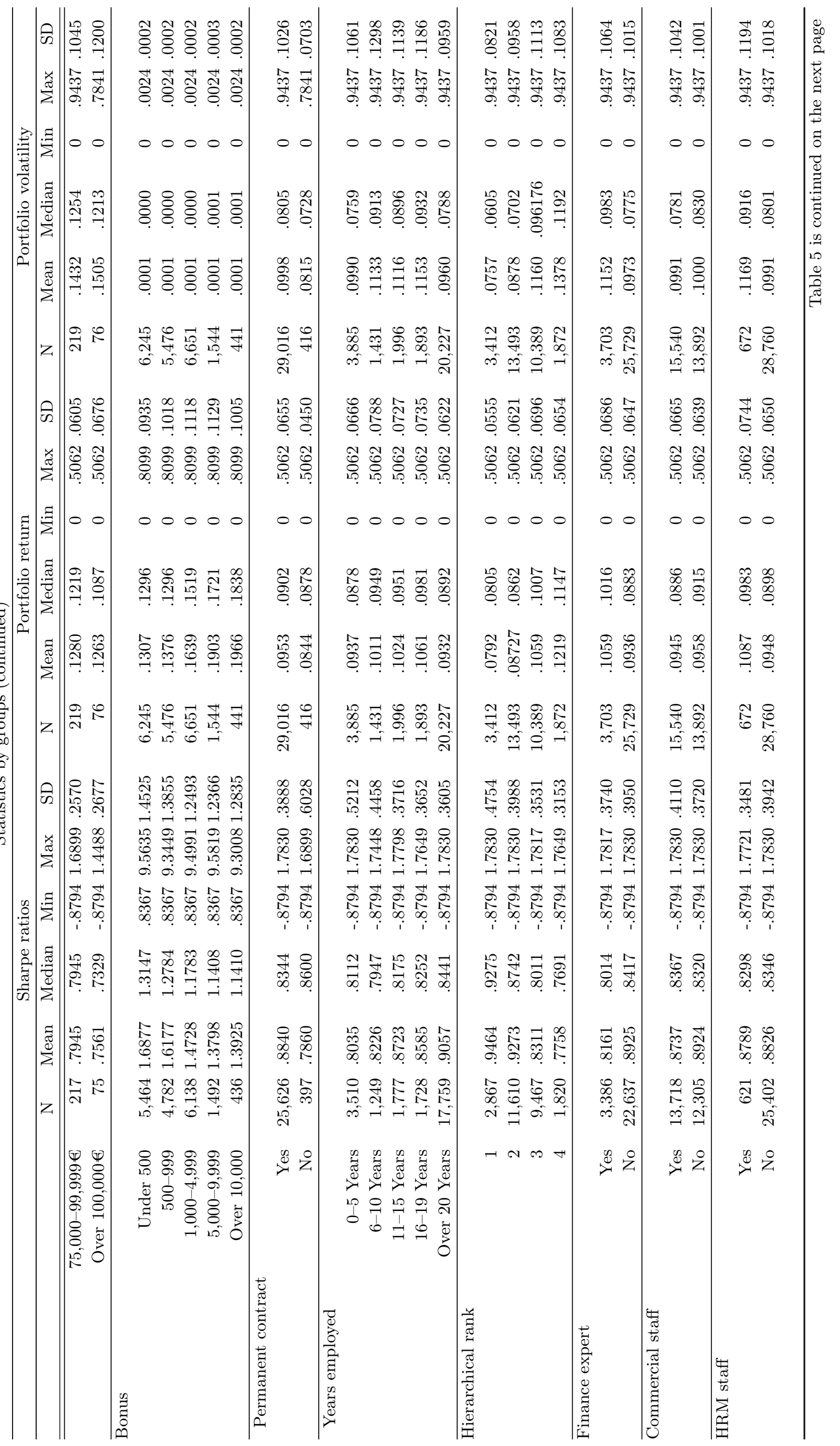




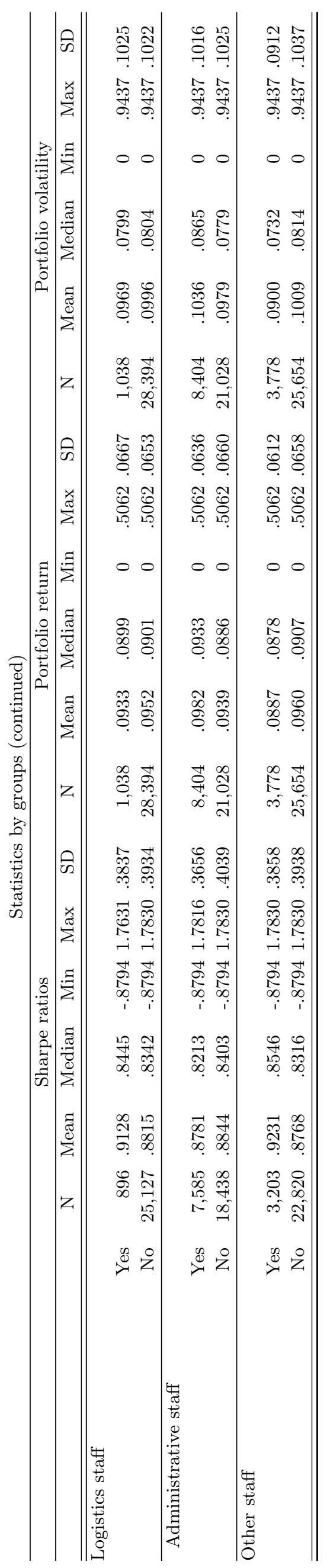




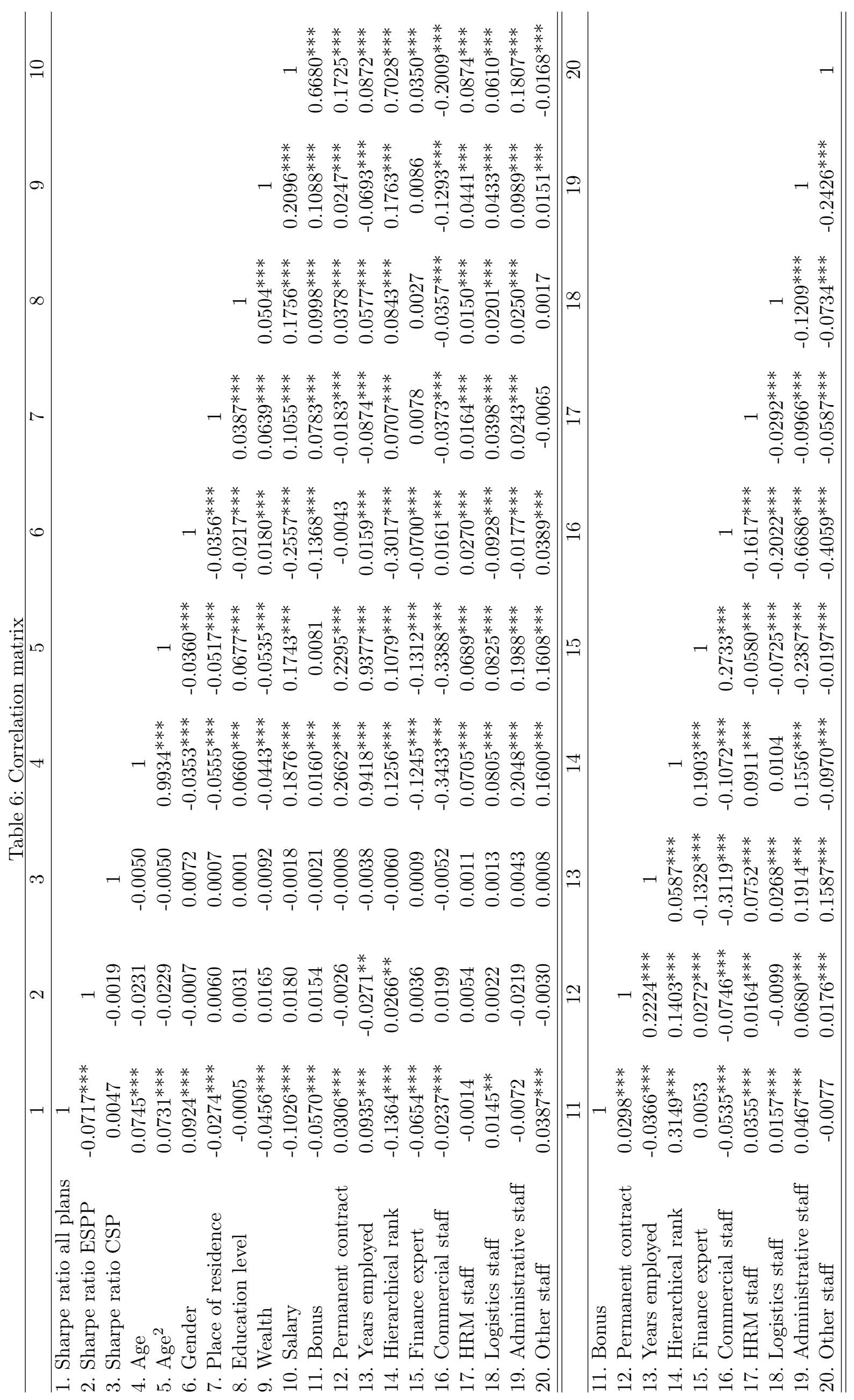


Table 7: All savings plan offered by the bank

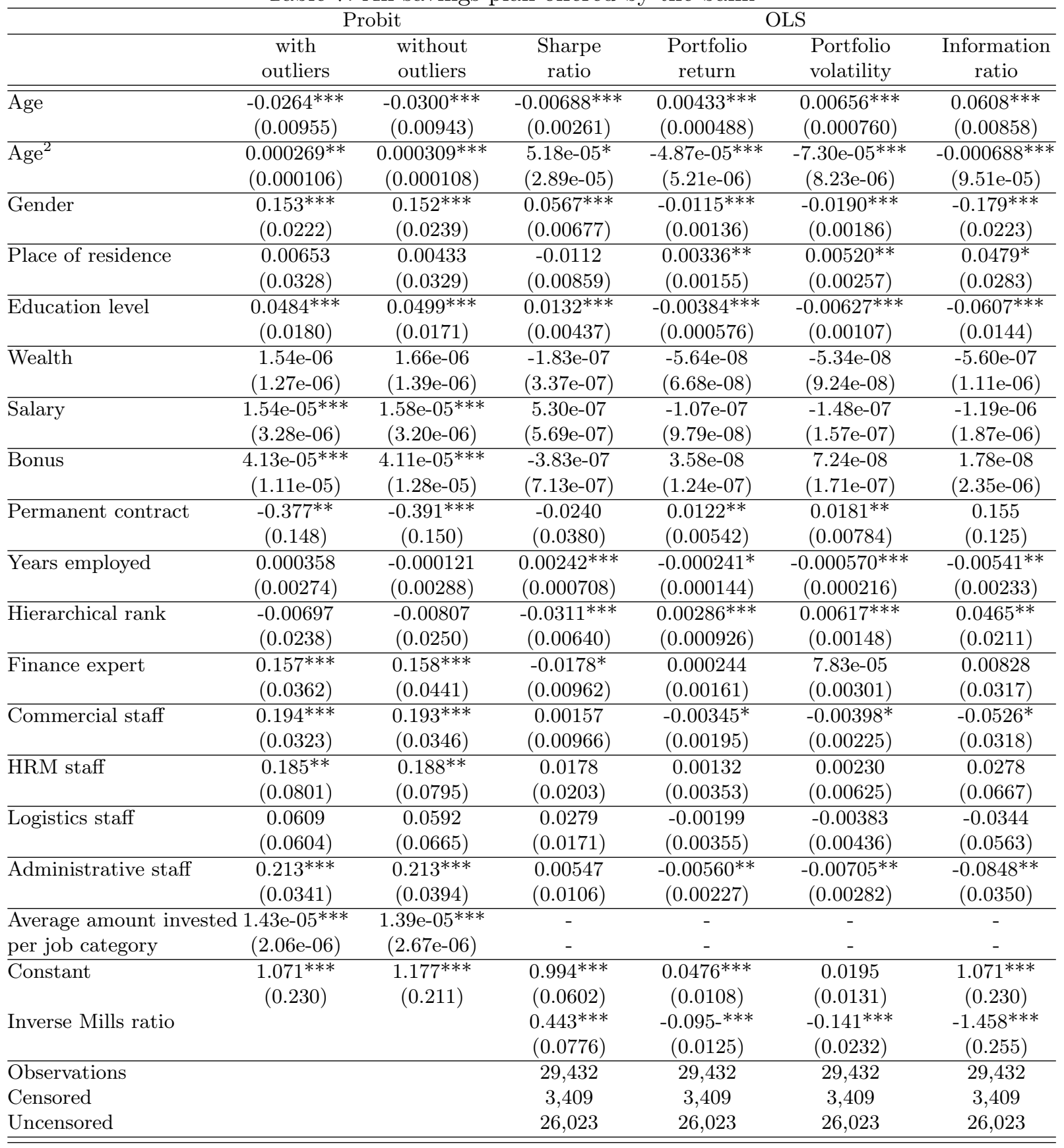

Notes: The "All Plans" table presents the results of the Heckman two-step model, in which the first step is a probit model, where the dependent variable is a dummy variable, which indicates whether the employee has held an investment or not in the two different plans proposed. While the second step is an ordinary least square (OLS) regression on the Sharpe ratios regressions of employees' characteristics. We have also provided the inverse Mills ratio for testing the presence of selection. T-statistics are reported in parenthesis, while for the significance level we will refer to the following typology: $*$ significant at $10 \%,{ }^{* *}$ significant at $5 \%, * * *$ significant at $1 \%$. 
Table 8: Company savings plan

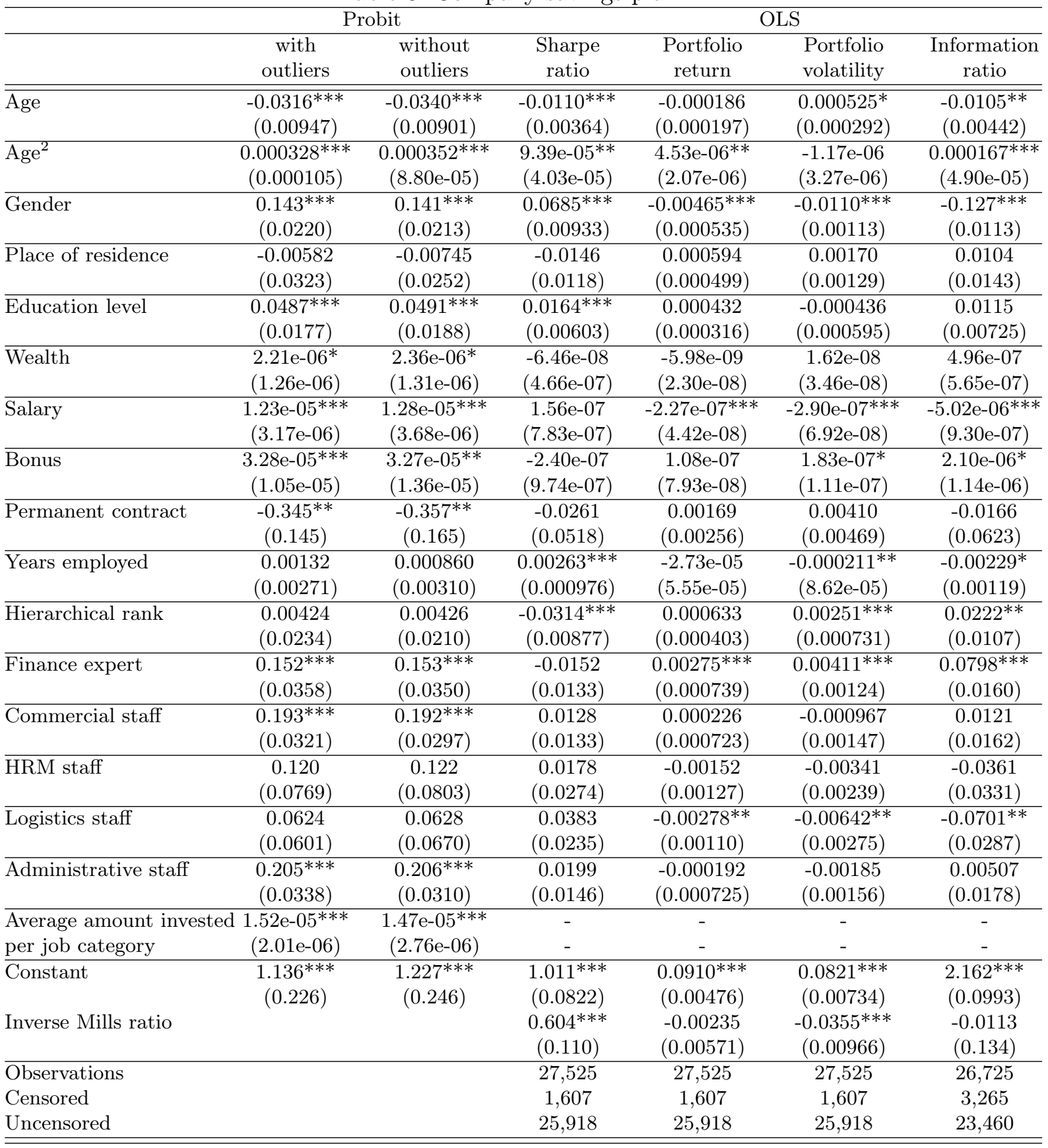

Notes: The "CSP" table presents the results of the Heckman two-step model, in which the first step is a probit model, where the dependent variable is a dummy variable, which indicates whether the employee has held an investment or not in the two different plans proposed. While the second step is an ordinary least square (OLS) regression on the Sharpe ratios regressions of employees' characteristics. We have also provided the inverse Mills ratio for testing the presence of selection. T-statistics are reported in parenthesis, while for the significance level we will refer to the following typology: ${ }^{*}$ significant at $10 \%,{ }^{* *}$ significant at $5 \%, * * *$ significant at $1 \%$. 
Table 9: Employee stock purchase plan

\begin{tabular}{|c|c|c|c|c|c|c|}
\hline & \multicolumn{2}{|c|}{ Probit } & \multicolumn{4}{|c|}{ OLS } \\
\hline & $\begin{array}{c}\text { with } \\
\text { outliers }\end{array}$ & $\begin{array}{l}\text { without } \\
\text { outliers }\end{array}$ & $\begin{array}{l}\text { Sharpe } \\
\text { ratio }\end{array}$ & $\begin{array}{l}\text { Portfolio } \\
\text { return }\end{array}$ & $\begin{array}{l}\text { Portfolio } \\
\text { volatility }\end{array}$ & $\begin{array}{c}\text { Information } \\
\text { ratio }\end{array}$ \\
\hline \multirow[t]{2}{*}{$\overline{\text { Age }}$} & $0.119^{* * *}$ & $0.117^{* * *}$ & $0.0210 * * *$ & $0.00539^{* * *}$ & $0.00918^{* *}$ & $0.107^{* * *}$ \\
\hline & $(0.00910)$ & $(0.00906)$ & $(0.00523)$ & $(0.00209)$ & $(0.00379)$ & $(0.0376)$ \\
\hline \multirow[t]{2}{*}{$\overline{\mathrm{Age}^{2}}$} & $-0.00135^{* * *}$ & $-0.00130^{* * *}$ & $-0.000303^{* * *}$ & $-8.09 \mathrm{e}-05^{* * *}$ & $-0.000136^{* * *}$ & $-0.00156^{* * *}$ \\
\hline & $(0.000100)$ & $(0.000102)$ & $(5.81 \mathrm{e}-05)$ & $(2.26 \mathrm{e}-05)$ & $(4.26 \mathrm{e}-05)$ & $(0.000418)$ \\
\hline \multirow[t]{2}{*}{ Gender } & $-0.0817^{* * *}$ & $-0.0785^{* * *}$ & $-0.0190^{* *}$ & $-0.00685^{* *}$ & $-0.0122^{* *}$ & $-0.131^{* *}$ \\
\hline & $(0.0195)$ & $(0.0191)$ & $(0.00778)$ & $(0.00281)$ & $(0.00565)$ & $(0.0559)$ \\
\hline \multirow[t]{2}{*}{ Place of residence } & $0.115^{* * *}$ & $0.105^{* * *}$ & 0.0155 & 0.00615 & 0.0104 & 0.108 \\
\hline & $(0.0274)$ & $(0.0292)$ & $(0.0104)$ & $(0.00411)$ & $(0.00647)$ & $(0.0749)$ \\
\hline \multirow[t]{2}{*}{ Education level } & $-0.0691^{* * *}$ & $-0.0656^{* * *}$ & $-0.0217^{* * *}$ & $-0.00728^{* * *}$ & $-0.0121^{* * *}$ & $-0.124^{* * *}$ \\
\hline & $(0.0141)$ & $(0.0159)$ & $(0.00517)$ & $(0.00183)$ & $(0.00381)$ & $(0.0372)$ \\
\hline \multirow[t]{2}{*}{ Wealth } & $3.26 \mathrm{e}-06^{* * *}$ & $3.21 \mathrm{e}-06^{* * *}$ & $-1.09 \mathrm{e}-07$ & $1.82 \mathrm{e}-08$ & $4.85 \mathrm{e}-08$ & $-3.24 \mathrm{e}-07$ \\
\hline & $(1.08 \mathrm{e}-06)$ & $(9.74 \mathrm{e}-07)$ & $(4.10 \mathrm{e}-07)$ & $(1.67 \mathrm{e}-07)$ & $(2.81 \mathrm{e}-07)$ & $(2.94 \mathrm{e}-06)$ \\
\hline \multirow[t]{2}{*}{ Salary } & $1.79 \mathrm{e}-05^{* * *}$ & $1.65 \mathrm{e}-05^{* * *}$ & $2.50 \mathrm{e}-06^{* * *}$ & $9.03 \mathrm{e}-07^{* * *}$ & $1.55 \mathrm{e}-06^{* * *}$ & $1.69 \mathrm{e}-05^{* * *}$ \\
\hline & $(1.72 \mathrm{e}-06)$ & $(3.45 \mathrm{e}-06)$ & $(7.78 \mathrm{e}-07)$ & $(3.09 \mathrm{e}-07)$ & $(5.68 \mathrm{e}-07)$ & $(5.58 \mathrm{e}-06)$ \\
\hline \multirow[t]{2}{*}{$\overline{\text { Bonus }}$} & $-9.88 \mathrm{e}-06^{* * *}$ & $-9.46 \mathrm{e}-06$ & $-1.66 \mathrm{e}-06^{*}$ & $-6.62 \mathrm{e}-07^{*}$ & $-1.19 \mathrm{e}-06^{*}$ & $-1.37 \mathrm{e}-05^{*}$ \\
\hline & $(1.92 \mathrm{e}-06)$ & $(1.52 \mathrm{e}-05)$ & $(9.86 \mathrm{e}-07)$ & $(3.51 \mathrm{e}-07)$ & $(6.99 \mathrm{e}-07)$ & $(7.08 \mathrm{e}-06)$ \\
\hline \multirow[t]{2}{*}{ Permanent contract } & 0.171 & 0.211 & -0.0545 & -0.0442 & -0.0492 & -0.600 \\
\hline & $(0.223)$ & $(0.215)$ & $(0.116)$ & $(0.101)$ & $(0.166)$ & $(0.839)$ \\
\hline \multirow[t]{2}{*}{ Years employed } & 0.000898 & 0.000456 & -0.000234 & -0.000397 & -0.000689 & -0.00604 \\
\hline & $(0.00226)$ & $(0.00195)$ & $(0.000787)$ & $(0.000322)$ & $(0.000543)$ & $(0.00565)$ \\
\hline \multirow[t]{2}{*}{ Hierarchical rank } & $0.189^{* * *}$ & $0.188^{* * *}$ & $0.0707^{* * *}$ & $0.0198^{* * *}$ & $0.0351^{* * *}$ & $0.342^{* * *}$ \\
\hline & $(0.0199)$ & $(0.0220)$ & $(0.0118)$ & $(0.00498)$ & $(0.00830)$ & $(0.0845)$ \\
\hline \multirow[t]{2}{*}{ Finance expert } & $0.127 * * *$ & $0.123^{* * *}$ & $0.0268^{* *}$ & 0.00427 & 0.00595 & 0.0757 \\
\hline & $(0.0281)$ & $(0.0265)$ & $(0.0110)$ & $(0.00525)$ & $(0.00817)$ & $(0.0792)$ \\
\hline \multirow[t]{2}{*}{ Commercial staff } & -0.00942 & -0.0230 & 0.0153 & $0.0101^{* *}$ & $0.0165^{* *}$ & $0.179^{* *}$ \\
\hline & $(0.0298)$ & $(0.0296)$ & $(0.0112)$ & $(0.00464)$ & $(0.00646)$ & $(0.0802)$ \\
\hline \multirow[t]{2}{*}{ HRM staff } & $0.222^{* * *}$ & $0.210^{* * *}$ & $0.0594^{* * *}$ & $0.0293^{* * *}$ & $0.0492^{* * *}$ & $0.546^{* * *}$ \\
\hline & $(0.0597)$ & $(0.0579)$ & $(0.0213)$ & $(0.00879)$ & $(0.0160)$ & $(0.153)$ \\
\hline \multirow[t]{2}{*}{ Logistics staff } & $-0.117^{* *}$ & $-0.111^{* *}$ & $0.0382^{*}$ & $0.0137^{*}$ & $0.0198^{* *}$ & $0.253^{*}$ \\
\hline & $(0.0567)$ & $(0.0504)$ & $(0.0208)$ & $(0.00763)$ & $(0.00966)$ & $(0.149)$ \\
\hline \multirow[t]{2}{*}{ Administrative staff } & -0.00451 & -0.00291 & $0.0279 * *$ & 0.00726 & $0.0120^{*}$ & $0.140^{*}$ \\
\hline & $(0.0308)$ & $(0.0304)$ & $(0.0114)$ & $(0.00470)$ & $(0.00662)$ & $(0.0822)$ \\
\hline \multirow{2}{*}{$\begin{array}{l}\text { Average amount invested } \\
\text { per job category }\end{array}$} & $1.20 \mathrm{e}-05^{* * *}$ & $1.28 \mathrm{e}-05^{* * *}$ & - & - & - & - \\
\hline & $(1.19 \mathrm{e}-06)$ & $(1.28 \mathrm{e}-06)$ & - & - & - & - \\
\hline \multirow[t]{2}{*}{ Constant } & $-4.629 * * *$ & $-4.595^{* * *}$ & $-0.447^{*}$ & -0.111 & -0.230 & -2.692 \\
\hline & $(0.275)$ & $(0.281)$ & $(0.228)$ & $(0.133)$ & $(0.224)$ & $(1.640)$ \\
\hline \multirow[t]{2}{*}{ Inverse Mills ratio } & & & $0.230 * * *$ & $0.0900^{* * *}$ & $0.156^{* * *}$ & $1.629^{* * *}$ \\
\hline & & & $(0.0425)$ & $(0.0183)$ & $(0.0355)$ & $(0.305)$ \\
\hline Observations & & & 27,525 & 27,525 & 27,525 & 26,888 \\
\hline Censored & & & 20,727 & 20,727 & 20,727 & 21,085 \\
\hline Uncensored & & & 6,798 & 6,798 & 6,798 & 5,803 \\
\hline
\end{tabular}

Notes: The "ESPP" table presents the results of the Heckman two-step model, in which the first step is a probit model, where the dependent variable is a dummy variable, which indicates whether the employee has held an investment or not in the two different plans proposed. While the second step is an ordinary least square (OLS) regression on the Sharpe ratios regressions of employees' characteristics. We have also provided the inverse Mills ratio for testing the presence of selection. T-statistics are reported in parenthesis, while for the significance level we will refer to the following typology: ${ }^{*}$ significant at $10 \%,{ }^{* *}$ significant at $5 \%, * * *$ significant at $1 \%$. 